\title{
Leonardo Kamibeppu
}

Imunoexpressão de caderinas e integrinas no

desenvolvimento do epitélio cutâneo humano

Dissertação apresentada à Faculdade de Medicina da Universidade de São Paulo para obtenção do Título de Mestre em Ciências

Programa de Dermatologia

Orientadora: Profa Dra Silvia Vanessa Lourenço

São Paulo 


\section{Leonardo Kamibeppu}

Imunoexpressão de caderinas e integrinas no

desenvolvimento do epitélio cutâneo humano

Dissertação apresentada à Faculdade de Medicina da Universidade de São Paulo para obtenção do Título de Mestre em Ciências

Programa de Dermatologia

Orientadora: Profa Dra Silvia Vanessa Lourenço

São Paulo 
Dados Internacionais de Catalogação na Publicação (CIP)

Preparada pela Biblioteca da

Faculdade de Medicina da Universidade de São Paulo

Creprodução autorizada pelo autor

Kamibeppu, Leonardo

Imunoexpressão de caderinas e integrinas no desenvolvimento do epitélio cutâneo humano / Leonardo Kamibeppu. -- São Paulo, 2011.

Dissertação(mestrado)--Faculdade de Medicina da Universidade de São Paulo.

Programa de Dermatologia.

Orientadora: Silvia Vanessa Lourenço.

Descritores: 1.Caderinas 2.Cadeias beta de integrinas 3.Integrina beta4

4.Epiderme 5.Citoqueratinas 6.Pele/embriologia 7.Moléculas de adesão celular

USP/FM/DBD-105/11 
Esta tese está de acordo com as seguintes normas, em vigor no momento desta publicação:

Referências: sistema autor-data; adaptado de International Committee of Medical Journals Editors (Vancouver)

Universidade de São Paulo. Faculdade de Medicina. Serviço de Biblioteca e Documentação. Guia de apresentação de dissertações, teses e monografias. Elaborado por Anneliese Carneiro da Cunha, Maria Julia de A. L. Freddi, Maria F. Crestana, Marinalva de Souza Aragão, Suely Campos Cardoso, Valéria Vilhena. 2으 ed. São Paulo: Serviço de Bibliotec e Documentação; 2005.

Abreveaturas dos Títulos dos periódicos de acordo com List of Journals Indexed in Index Medicus. 
DEDICATÓRIA 
Eu dedico este trabalho

aos amigos, os quais sempre me apoiaram e torceram; aos meus familiares, em especial aos meus pais e em memória a minha avó 
AGRADECIMENTOS 


\section{AGRADECIMENTOS}

Eu sou muito grato a todas as pessoas que me acompanharam e me deram oportunidade em poder desenvolver este trabalho ao qual me sinto bastante honrado em ter participado e que significou muito para mim profissionalmente e pessoalmente; em especial:

À Profa Dra Silvia Vanessa Lourenço que foi uma orientadora espetacular nesses oito anos que estagiei; eu realmente fui um grande felizardo em poder absorver um pouco do vasto conhecimento e vivência dessa grande profissional e pessoa que sempre me motivou a crescer profissionalmente e a desenvolver a autoconfiança da qual eu não havia encontrado;

À Dra Dirce Mary Correia Meissel que sempre me dirigiu uma palavra de conforto nos momentos mais críticos da minha vida e me ensinou muito com a sua experiência profissional e as suas palavras amigas;

Às técnicas de laboratório da Dermatologia; Jaqueline M Cruz Aragão, Maria Cristina Galhardo, Marlene Contini e Luciana Fontana Cassimiro, as quais me mostraram a rotina do laboratório, pacientemente me ensinaram logo no início do meu estágio e sempre me ajudaram no preparo das lâminas; 
À Biomédica Joyce Kawakami e a minha amiga da faculdade Márcia Helena Volpini Leosvaldo que me ajudaram a conseguir o tão sonhado estágio na USP e me permitiram concretizar um grande sonho;

Aos Professores e Doutores Pedro Paulo Chieffi e Ronaldo Griensk;

Ao Departamento de Dermatologia e ao Laboratório de Investigação Médica (LIM 06) que me possibilitaram desenvolver e realizar a minha pós-gradução;

Aos colegas do Instituto de Medicina Tropical;

À Fundação de Amparo à Pesquisa do Estado de São Paulo (Fapesp) que aprovou e incentivou o desenvolvimento científico deste trabalho. 
SUMÁRIO 
SUMÁRIO

Lista de abreviaturas

Lista de símbolos

Lista de figuras

Lista de quadros

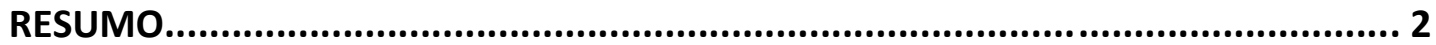

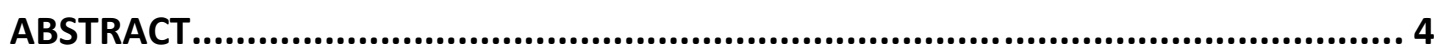

1 INTRODUÇÃO

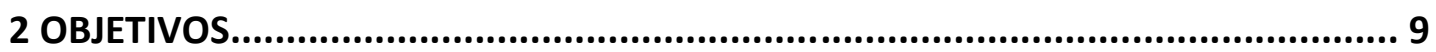

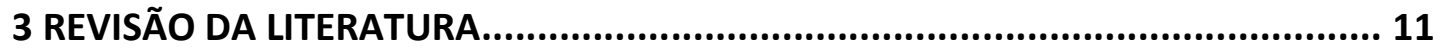

3.1 O Desenvolvimento Tegumentar................................................................. 11

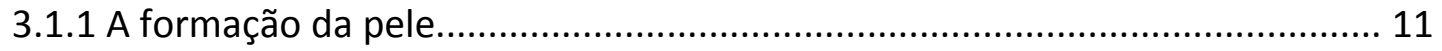

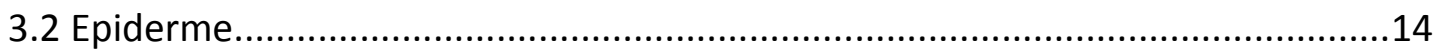

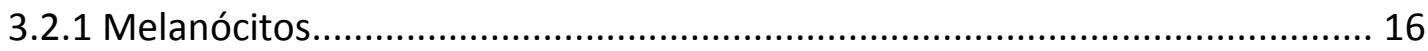

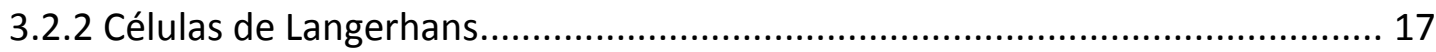

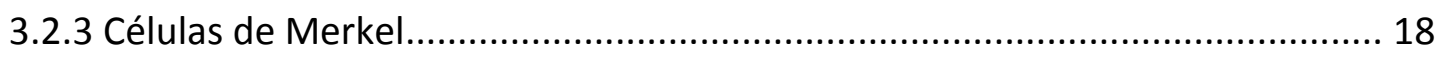

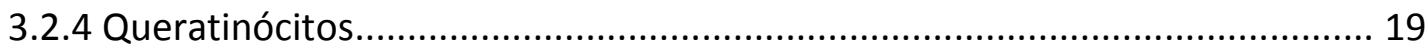

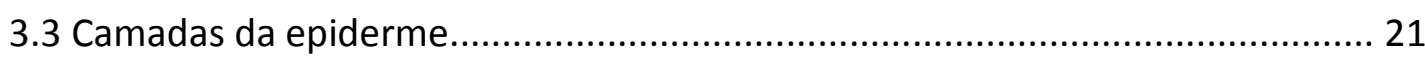

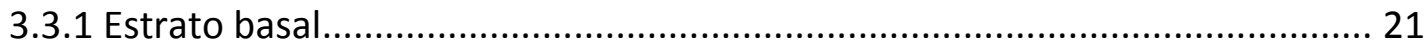

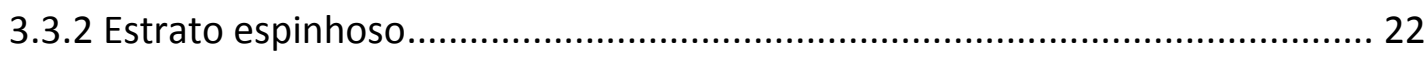

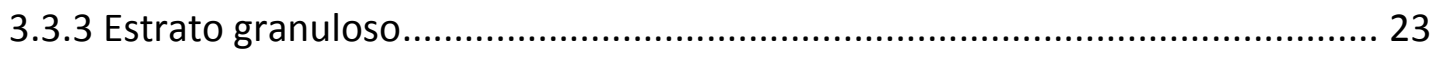

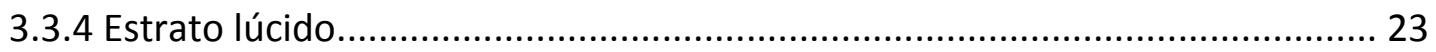




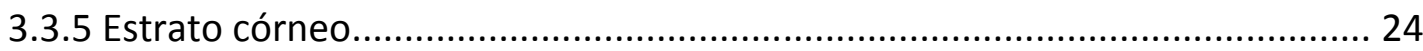

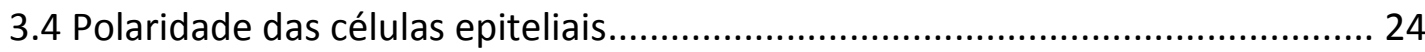

3.5 Processo de diferenciação dos queratinócitos ................................................... 25

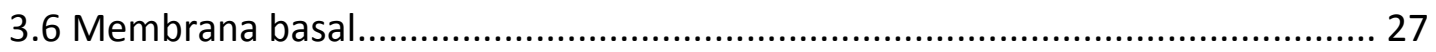

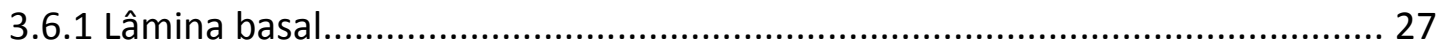

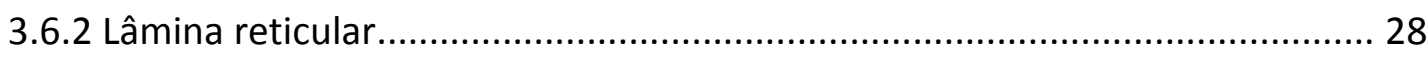

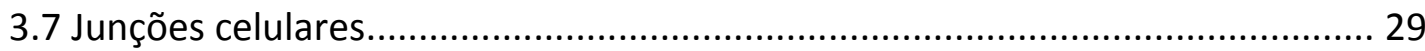

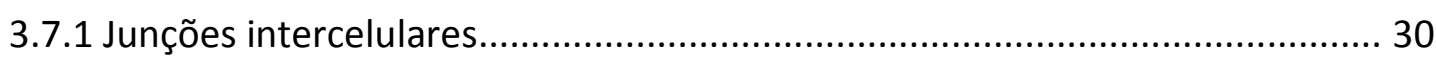

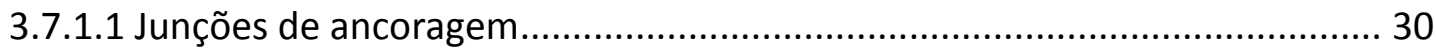

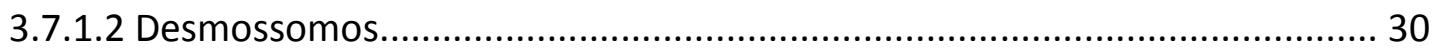

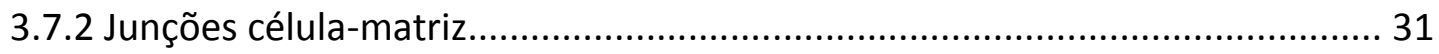

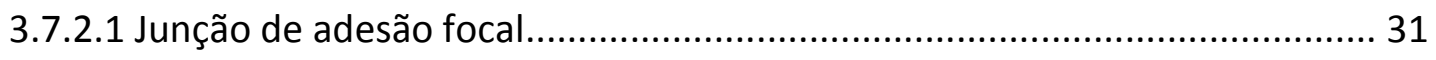

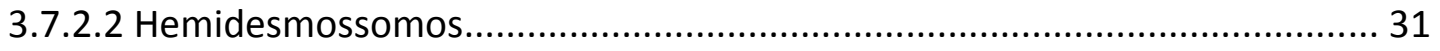

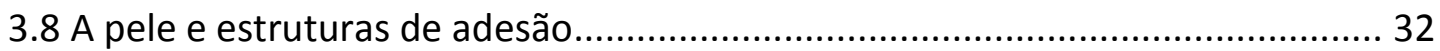

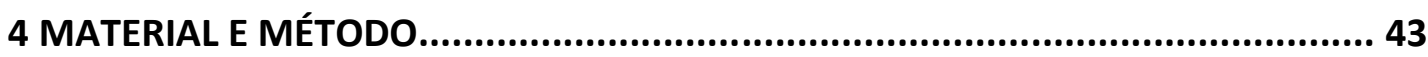

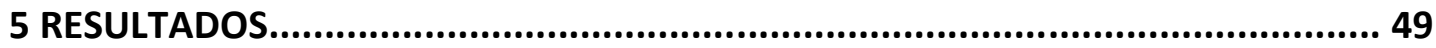

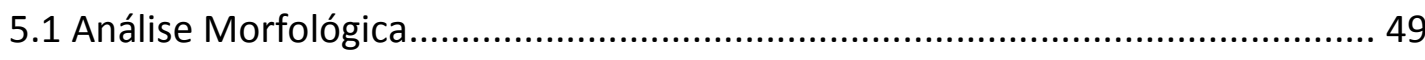

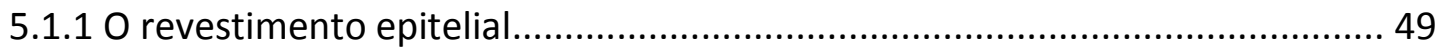

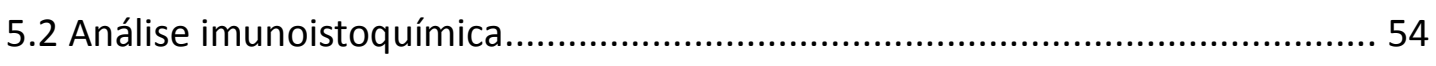

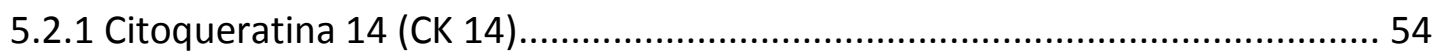

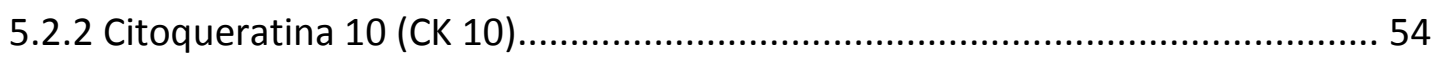

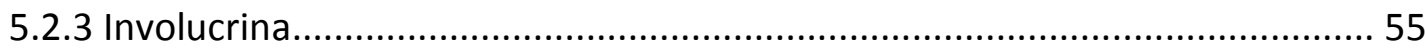

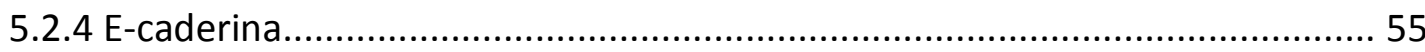




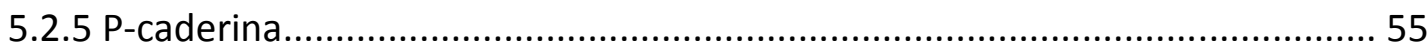

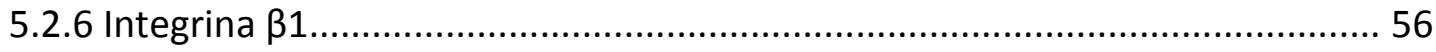

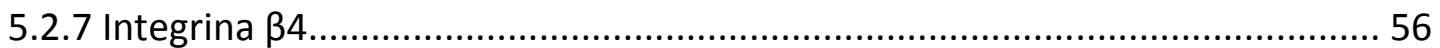

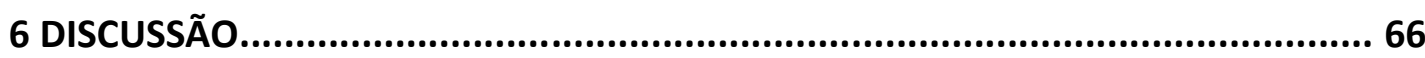

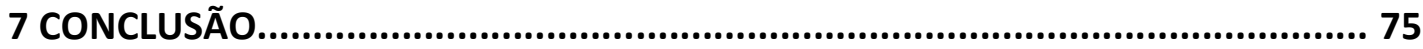

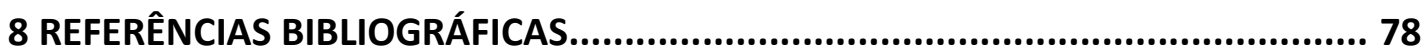

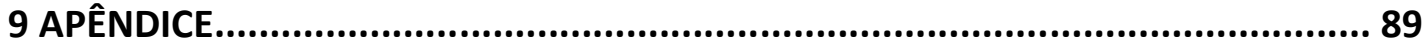




\section{Lista de Abreviaturas}

$\begin{array}{ll}\text { Arg } & \text { Arginina } \\ \text { Asp } & \text { Aspartato/ Ácido aspartico } \\ \mathrm{Ca}^{++} & \text {Glicina } \\ \mathrm{Mg}^{++} & \text {Cátion cálcio } \\ \mathrm{CK}^{+} & \text {Cátion magnésio } \\ \mathrm{Dab} & \text { Citoqueratina } \\ \text { et al } & \text { Diaminobenzidina } \\ \mathrm{INV} & \text { E outros } \\ \mathrm{KD} & \text { Involucrina } \\ \mathrm{M \mu} & \text { Kilodaltons } \\ \mathrm{Nm} & \text { Micrômeros } \\ \mathrm{mm} & \text { Nanômetros } \\ \mathrm{VIU} & \text { Milímetros por quadrado } \\ \end{array}$


Lista de Símbolos

$\alpha$

Alfa

$\beta$

Beta

$\%$

Porcentagem

$x$

Vezes 


\section{Lista de Figuras}

Figura $1(A-H)$ : Exemplos de estruturas presente no desenvolvimento da pele, pela análise morfológica- Hematoxilina e eosina

Figura 2 (A-L): Expressão de integrinas e caderinas na pele fetal

humana.......

58

Figura $3(\mathrm{~A}-\mathrm{L})$ : Expressão das citoqueratinas 10 e 14 e involucrina na pele fetal humana.

Figura 4 (A-C): Expressão das integrinas e caderinas na pele humana

adulta. 



\section{Lista de Quadros}

Quadro 1- Etapas do desenvolvimento fetal........................................................... 13

Quadro 2- Descrição e distribuição das caderinas.................................................. 36

Quadro 3- Descrição dos embriões/ fetos estudados............................................ 44

Quadro 4- Anticorpos monoclonais utilizados e peculiaridades do protocolo......... 47

Quadro 5- Distribuição das caderinas, integrinas, citoqueratinas e involucrinas nas

diferentes camadas epiteliais em desenvolvimento intrauterino......................... 57 
Kamibeppu L. Imunoexpressão de Caderinas e Integrinas no desenvolvimento do epitélio cutâneo humano

[Dissertação]. São Paulo; 2011.90p. 


\section{RESUMO}

Introdução: Caderinas e integrinas são importantes para a manutenção da integridade tecidual e transdução de sinal durante o desenvolvimento da pele. A distribuição destas moléculas no desenvolvimento da pele humana foi investigada e associada com os marcadores de diferenciação, Citoqueratinas (CK) e involucrina (INV). Método: Usando a técnica de imunoistoquímica foram investigadas as proteínas E- e P-caderinas, integrinas beta- 1 e -4, CK 10, CK 14 e INV em fragmentos de pele de várias regiões corpóreas de 7 fetos humanos (semana gestacional de 4 a 24, todos pesando até 500 g). Resultados: $\mathrm{Na}$ fase inicial do desenvolvimento, integrinas beta-1 e -4 and E- and P- caderinas estavam presentes na membrana plasmática das células epiteliais em todos as camadas do epitélio. CK14 e CK10 foram observadas em todas as camadas epiteliais e a INV fracamente detectada em células da camada mais superficial. Em estágios mais avançados, integrinas foram detectadas em todas as camadas epiteliais, com expressão polarizada principalmente na camada basal. E- caderina foi detctada em todas as camadas, menos no estrato cornificado e a P- caderina foi observada em camadas mais profundas do epitélio. CK14 estava presente na camada basal, CK 10 no estrato suprabasal e a INV foi observada no estrato cornificado. Conclusão: Caderinas e integrinas são essenciais para o desenvolvimento da pele, sendo espacialmente e temporalmente regulados. Suas expressões são relatas com a expressão da maturação de marcadores da epiderme.

Descritores: 1. Caderinas 2. Integrinas 3. Integrina beta 4 4. Epiderme 5. Citoqueratina 6. Pele/embriologia 7. Moléculas de adesão celular 
SUMMARY 


\section{SUMMARY}

Introduction: Cadherins and integrins are important for maintenance of tissue integrity and in signal transduction during skin development. Distribution of these molecules in human skin development was investigated and associated with markers of differentiation, cytokeratins (CK) and involucrin (INV).

Methods: Using immunohistochemistry expression of E- and P- cadherins, integrins beta-1 and -4, CK10, CK 14 and INV was assessed in skin fragments of 7 human fetuses (gestacional weeks ranged from 4 to 24 , all weighing up to $500 \mathrm{~g}$ ).

Results: At initial phases of development, integrins beta-1 and -4 and $\mathrm{E}$ - and P- cadherins were present on epithelial cell membranes in all layers. CK 14 and CK 10 were expressed in all epithelial layers and INV weakly detected in the superficial layer. In more advanced stages, integrins were detected in all layers, but a marked polarized expression was seen in basal layer. E- cadherin was detected in all layers, but the cornified stratum and P-cadherin were observed in the lower layers. CK 14 was expressed in layer, CK 10 in suprabasal stratum and INV was observed in cornified layer.

Conclusions: Cadherins and integrins are essential for skin development, being spatially and temporally regulated. Their expression is related with the expression of maturation markers of the epidermis.

Descriptors: 1. Cadherin 2. Integrin 3. Integrin beta 4 4. Epiderme 5 Cytokeratin 6. Skin/embriology 7. Cell adhesion molecules 
1 INTRODUÇÃO 


\section{INTRODUÇÃO}

O desenvolvimento humano envolve o rápido crescimento do corpo e a diferenciação dos tecidos e órgãos que começam a se formar no período embrionário. período fetal humano corresponde ao estágio de desenvolvimento intrauterino que começa a partir da nona semana e prolonga-se até o nascimento, aproximadamente na trigésima oitava semana de gestação. Neste período ocorrem mudanças significativas quanto à pele e seus anexos cutâneos, pois caberá ao tecido tegumentar assegurar a integridade ao recém nascido, ao entrar em contato com o meio externo (Moore, 2000).

As interações ectoderma (epiderme)/ mesênquima (derme) envolvem mecanismos de indução mútua, levando a um processo de especialização dos tecidos que é marcado pela diferenciação celular. Nele ocorre uma série de modificações bioquímicas, morfológicas e funcionais que transformam uma célula primitiva indiferenciada, que executa apenas as funções celulares básicas, essenciais para a sobrevivência da própria célula, em uma célula capaz de realizar algumas funções com grande eficiência. A diferenciação celular é um processo importante durante o desenvolvimento embrionário e depende da ativação e inativação diferencial de determinados genes (Junqueira \& Carneiro, 2004).

A matriz extracelular (MEC) exerce uma influência considerável sobre o comportamento das células individuais, transmitindo-lhes informações espaciais que são fundamentais para o desenvolvimento, diferenciação, função celular normal e resistência à apoptose (Cooper, 2002).

Os componentes da MEC podem também gerar sinais co-estimulantes, por exemplo, por meio de sinais ativados pela ligação da integrina ou como resultado da 
homologia com o fator de crescimento epidérmico (proteoglicanos modulares). Ainda, a adesão celular é essencial não apenas no desenvolvimento, mas também no crescimento normal, na cicatrização de lesões, no remodelamento tecidual e no sistema imune (Cooper, 2002).

Várias classes de moléculas de adesão do tipo célula- célula são importantes para o desenvolvimento e maturação e manutenção da pele. Dessas, a E- e P-caderina e integrinas beta-1 e beta-4 são importantes não só para a adesão célula- célula e a manutenção da integridade tecidual, mas também para a transdução de sinal e evolução do desenvolvimento dos estágios de desenvolvimento histo e morfogênico para conduzir a um tecido adulto e maturo (Furukawa et al, 1997). 
2 OBJETIVOS 


\section{OBJETIVOS}

Dada a importância das moléculas de adesão no desenvolvimento e manutenção de organismos multicelulares, nossos objetivos serão:

\subsection{Objetivos Gerais:}

Investigar as classes das principais moléculas de adesão - caderinas e integrinas - no desenvolvimento do epitélio cutâneo e correlacioná-las com marcadores da diferenciação epitelial.

\subsection{Objetivos Específicos}

1. Investigação da presença e a topografia de caderinas nas fases do desenvolvimento do epitélio cutâneo de fetos humanos;

2. Investigação da presença e a topografia de integrinas nas fases do desenvolvimento do epitélio cutâneo de fetos humanos;

3. Correlacionar a expressão das moléculas de caderinas e integrinas com a expressão de marcadores da maturação do epitélio cutâneo - citoqueratinas e involucrina. 
3 REVISÃO DA LITERATURA 


\section{REVISÃO DA LITERATURA}

\subsection{O DESENVOLVIMENTO TEGUMENTAR}

\subsubsection{A FORMAÇÃO DA PELE}

A pele é formada por dois compartimentos, a epiderme e a derme, originados de dois folhetos germinativos distintos. A epiderme é o tecido epitelial de superfície e é derivada do ectoderma cutâneo (Persaud \& Moore, 2008). Já derme é a camada mais profunda e derivada do mesoderma. A rede de tecido conjuntivo embrionário subjacente (mesênquima), derivado do mesoderma, forma o tecido conjuntivo da derme (Persaud \& Moore, 2008). A Camada mais profunda da derme, a hipoderme, apresenta grandes quantidades de tecido adiposo (Sadler, 1997).

Inicialmente, o ectoderma superficial que recobre o embrião é constituído por uma camada com a espessura de uma única célula. Na quarta semana no processo de neurulação, o ectoderma superficial prolifera e forma uma nova camada de epitélio pavimentoso simples denominado periderme. A camada de células em proliferação, subjacente, é agora denominada camada basal separada da 
derme pela membrana basal e é constituída por colágenos, laminina e fibronectina. As células da periderme descamam gradualmente caindo no líquido amniótico; a periderme está totalmente descamada por volta da vigésima primeira semana. Aproximadamente na décima primeira semana, a proliferação da camada basal produz uma nova camada intermediária logo abaixo da periderme e esta camada será precursora das camadas externa da epiderme madura. A camada basal, agora denominada germinativa, constitui a camada de células-tronco. Inicialmente no quinto mês de vida intrauterina, aproximadamente o período em que a periderme desaparece, a camada intermediária é substituída por três camadas definitivas de queratinócitos: a camada espinhosa, a camada granulosa e a camada córnea (Carlston, 1994).

A derme, tecido conjuntivo que dá sustentação à epiderme, forma-se a partir do mesênquima, que se origina da camada somática do mesoderma lateral e dos dermátomos dos somitos. Com onze semanas, as células mesenquimais já começam a produzir fibras do tecido conjuntivo, colágenos e elásticas (Persaud \& Moore, 2008).

Os estágios do desenvolvimento fetal e suas respectivas características são demonstrados no Quadro 1. 
Quadro 1 - Etapas do desenvolvimento fetal

\begin{tabular}{|c|c|c|c|c|}
\hline $\begin{array}{l}\text { IDADE } \\
\text { SEMANAS }\end{array}$ & $\begin{array}{c}\text { PESO } \\
\text { (GRAMAS) }\end{array}$ & $\begin{array}{l}\text { COMPRIMENTO } \\
\text { DO PÉ (mm) }\end{array}$ & $\begin{array}{l}\text { COMPRIMENTO } \\
\text { CR (mm) }\end{array}$ & PRINCIPAIS CARACTERÍSTICAS EXTERNAS \\
\hline 9 & 8 & 7 & 50 & $\begin{array}{l}\text { Olhos estão fechados, ou se fechando, genitália } \\
\text { externa não é distinguível entre ambos os sexos }\end{array}$ \\
\hline 10 & 14 & 9 & 61 & $\begin{array}{l}\text { Intestinos no abdome, início de formação das unhas } \\
\text { das mãos }\end{array}$ \\
\hline 12 & 45 & 14 & 87 & Sexo distinguível externamente \\
\hline 14 & 110 & 20 & 120 & $\begin{array}{c}\text { Cabeça ereta, membros inferiores bem } \\
\text { desenvolvidos, início da formação das unhas dos pés }\end{array}$ \\
\hline 16 & 200 & 27 & 140 & Orelhas externas destacadas da cabeça \\
\hline 18 & 320 & 33 & 160 & $\begin{array}{l}\text { Vernix caseosa cobre a pele, movimentos são } \\
\text { percebidos pela mãe }\end{array}$ \\
\hline 20 & 460 & 39 & 190 & Cabelos e pêlos do corpo (lanugo) são visíveis \\
\hline 22 & 630 & 45 & 210 & Pele enrugada, translúcida, de rosada a vermelha \\
\hline 24 & 820 & 50 & 230 & Unhas dos dedos das mãos estão presentes \\
\hline 26 & 1000 & 55 & 250 & Olhos parcialmente abertos, cílios presentes \\
\hline 28 & 1300 & 59 & 270 & $\begin{array}{c}\text { Olhos bem abertos, boa quantidade de cabelos } \\
\text { presentes, pele ligeiramente enrugada }\end{array}$ \\
\hline 30 & 1700 & 63 & 280 & $\begin{array}{l}\text { Unhas dos dedos dos pés presentes, corpo adquire } \\
\text { músculos, testículos descendo }\end{array}$ \\
\hline 32 & 2100 & 68 & 300 & Pele rosada e lisa \\
\hline 36 & 2900 & 79 & 340 & $\begin{array}{c}\text { Corpo ligeiramente roliço, pêlos do lanugo quase } \\
\text { ausentes }\end{array}$ \\
\hline 38 & 3400 & 83 & 360 & Tórax saliente \\
\hline \multicolumn{5}{|c|}{ CRL- Crown length (vértice- nádegas).Esses pesos referem-se a fetos que foram fixados cerca de 2 semanas em formol a $10 \%$. } \\
\hline
\end{tabular}




\subsection{EPIDERME}

Inicialmente, o embrião está recoberto por uma única camada de células ectodérmicas. No segundo mês a periderme ou epitríquio, é depositada sobre a superfície, constituindo dessa forma duas camadas distintas, sendo uma mais superficial e formada por epitélio pavimentoso constituído por células achatadas (periderme). As células da periderme sofrem queratinização e descamação contínua, sendo substituídas por células originadas da camada basal. Com a proliferação celular na zona basal, forma-se uma terceira camada, a zona intermediária. Finalmente, na metade da gestação, as camadas epiteliais da epiderme adquirem disposição definitiva de epitélio estratificado pavimentoso córneo e com as suas quatro camadas características; o estrato basal, espinhoso, granuloso e córneo. A transformação do ectoderma superficial em uma epiderme de múltiplas camadas resulta das contínuas interações de indução com a derme (Persaud \& Moore, 2008 ; Belda et al, 2010).

Durante o primeiro e o segundo trimestre de vida intrauterina, o crescimento da epiderme ocorre em estágios que resultam no aumento da sua espessura (Persaud \& Moore, 2008 ; Belda et al, 2010).

Neste período ocorrem mudanças significativas quanto à pele e seus anexos cutâneos, pois caberá ao tecido tegumentar assegurar a integridade do recém nascido, ao entrar em contato com meio externo. Neste período, o feto com aproximadamente dezoito semanas possui a pele revestida por uma substância 
gordurosa caseosa, a vérnix caseosa (Moore, 2000). Esta substância é constituída por células epidérmicas e pêlos degenerados, e pela secreção gordurosa de glândulas sebáceas produzidas pela pele do feto. Ela protege a pele contra a ação de maceração do líquido amniótico. Com vinte semanas de vida intrauterina, o corpo fetal está revestido por pêlos macios, o lanugo, que ajudarão na retenção da vérnix caseosa pela pele (Moore, 2000).

A interface entre a epiderme e a derme apresenta cristas elevadas, as cristas dérmicas (papilas) que se entrelaçam com invaginações da epiderme denominadas cristas epidérmicas. Coletivamente, estes dois tipos de cristas são denominados rete apparatus. Invaginações adicionais de derivados da epiderme (exemplo folículos pilosos, glândulas sudoríparas e glândulas sebáceas) localizadas na derme, fazem com que esta interface tenha um contorno irregular (Gartner \& Hiatt, 2003).

A superfície das polpas dos dedos e dos artelhos tem cristas e sulcos alternados que formam alças, curvas e vórtices com determinados padrões denominados dermatóglifos (impressões digitais), que se formam ainda no feto e permanecem sem modificações durante toda a vida (Gartner \& Hiatt, 2003).

Na maior parte do corpo a espessura da epiderme varia entre 0,07 a 0,12 $\mathrm{mm}$, com espessamentos localizados nas palmas das mãos e sola dos pés, onde a sua espessura pode variar de $0,8 \mathrm{~mm}$ a $1,4 \mathrm{~mm}$, respectivamente. A pele mais espessa das palmas e sola já é evidente nos fetos. A pele espessa cobre as palmas das mãos e sola dos pés. Sua espessura varia de 400 a $600 \mu m$, e caracteriza-se pela presença de todas as cinco camadas. Não possui folículos pilosos e glândulas sebáceas, mas possui muitas glândulas sudoríparas. A pele fina reveste a maior 
parte do corpo; a sua espessura varia de 75 a $150 \mu m$, apresenta estrato córneo delgado, não possui estrato lúcido ou estrato granuloso bem definido e apresenta anexos cutâneos (Gartner \& Hiatt, 2003).

O epitélio estratificado pavimentoso queratinizado da pele é constituído por quatro tipos celulares: queratinócitos, melanócitos, células de Langerhans e Merkel.

\subsubsection{MELANÓCITOS}

Durante o primeiro trimestre do desenvolvimento, células da crista neural migram para o mesênquima da derme em desenvolvimento e se diferenciam em melanoblastos. Mais tarde estas células esféricas migram para junção dermoepidérmica e se diferenciam em melanócitos. A diferenciação de melanoblastos em melanócitos envolve a formação de grânulos de pigmentos e a aquisição de um aspecto mais alongado. Estas novas células diferenciadas sintetizam o pigmento melanina, o qual pode ser transferido para outras células da epiderme através dos prolongamentos dendríticos. Os melanócitos aparecem na pele em desenvolvimento entre 40 a 50 dias, imediatamente após a migração das células da crista neural. Os melanócitos começam a produzir o pigmento melânico antes do nascimento e a distribuem para as células epidérmicas. Quantidades aumentadas de melanina são produzidas em resposta à luz ultra-violeta e conseqüentemente há como resultado o bronzeamento. O conteúdo relativo de 
melanina nos melanócitos é o responsável pelas variações de cor de pele (Persaud \& Moore, 2003).

Os melanócitos apresentam coloração pálida, com grandes núcleos ovóides e citoplasma abundante, a partir do qual numerosos prolongamentos citoplasmáticos longos se estendem para os espaços entre os queratinócitos (Zhang, 1999). O citoplasma dos melanócitos contém grânulos ovóides ligados à membrana (pré-melanossomos e melanossomos). O número de melanócitos apresenta-se constante, mas seu grau de atividade é geneticamente variável conforme a variação racial e individual da cor da pele (Steven \& Lowe, 2001).

A melanina será responsável pela pigmentação da pele e atenuação dos efeitos nocivos causados pela radiação ultravioleta. A relação entre os melanócitos e queratinócitos basais varia em relação à região corpórea na relação de 1:5 a 1:10 (Kerr, 2000).

\subsubsection{CÉLULAS DE LANGERHANS}

Algumas vezes também são denominadas como células dendríticas devido aos seus numerosos e longos prolongamentos citoplasmáticos. Originam-se de precursores vindos da medula óssea e são transportadas pelo sistema vascular. Fazem parte do sistema mononuclear fagocitário. Pertencem ao sistema imune e cuidam da defesa imunológica da pele, pois são células apresentadoras de antígeno 
que cooperam com linfócitos T na pele a fim de dar início a respostas mediadas por células contra antígenos estranhos (Gartner \& Hiatt, 2003).

As células de Langerhans representam de 2 a $4 \%$ da população de células epidérmicas, o seu número pode chegar a 800 por milímetro quadrado. Estão primariamente localizadas no estrato espinhoso (Gartner \& Hiatt, 2003). As células de Langerhans estão presentes em pequeno número (cerca de 65 células $/ \mathrm{mm}^{2}$ de epiderme) durante os dois primeiros trimestres da gestação. Este número aumenta para 2 a $6 \%$ do número total de células epidérmicas no adulto. Como os melanócitos, apresentam um núcleo ovóide, pálido e envolvido por um citoplasma claro com prolongamentos citoplasmáticos (dendríticos) que se irradiam do citoplasma celular para o espaço intercelular entre os queratinócitos (Zhang, 1999).

\subsubsection{CÉLULAS DE MERKEL}

As células de Merkel são encontradas entre os queratinócitos do estrato basal da epiderme e tecido conjuntivo da derme (Zhang, 1999).

São abundantes na ponta dos dedos, em áreas desprovidas de pêlos e em regiões do corpo mais sensíveis ao toque. Localizam-se na parte profunda da epiderme, apoiadas na membrana basal e presas aos queratinócitos por meio de desmosomos. A parte apical da célula estende várias projeções alargadas e 
digitiformes para dentro da camada dos queratinócitos. Desmosomos ancoram a célula de Merkel e as células circundantes (Kessel, 2004).

Elas estão unidas aos queratinócitos adjacentes por desmosomos e em comunicação com terminações nervosas aferentes e são capazes de modificar os estímulos recebidos pelos neurônios sensitivos. (Kerr, 2000; Kierszenbaum, 2008).

Assemelham-se aos melanócitos e podem aparecer como células solitárias ou em agregados quando associadas ao disco piloso localizado imediatamente abaixo da basal. Acredita-se que tais agregados sejam receptores táteis, sendo algumas vezes, denominados corpúsculos táteis (Steven \& Lowe, 2001).

\subsubsection{QUERATINÓCITOS}

Os queratinócitos formam a maior população de células. Como os queratinócitos descamam constantemente da superfície da epiderme, esta população precisa ser continuamente renovada. Esta renovação se dá através da atividade mitótica dos queratinócitos da camada basal da epiderme. Ao longo de seu trajeto em direção à superfície, transladam para o estrato espinhoso e deste para o granuloso, passando para o córneo onde se descamam. Esta diferenciação que sofre o queratinócito se deve primordialmente ao acúmulo em seu citoplasma de filamentos intermediários de queratina. 
O estrato córneo não é celular, ele é um composto totalmente formado de remanescentes citoplasmáticos de queratina depositados na superfície após a morte dos queratinócitos.

Os queratinócitos que se situam acima da camada basal constituem a camada espinhosa, células poliédricas, com núcleos redondos centrais e citoplasma que se cora em róseo pela técnica histoquímica da hematoxilina e eosina. A queratina forma filamentos de cerca de 10nm no citoplasma dos queratinócitos. Já foram identificados aproximadamente 10 tipos diferentes de queratina, e quatro destas estão presentes na epiderme. As células do estrato basal sintetizam duas das quatro queratinas (CK5 e CK14), enquanto as células do estrato espinhoso sintetizam as outras duas, que tendem a formar feixes mais grosseiros de filamentos (CK1 e CK10) (Gartner \& Hiatt, 2003; Moll, 1983).

A medida que as células se diferenciam e se deslocam pelo epitélio estratificado, elas permanecem ligadas por junções desmossômicas e as proteínas de citoqueratinas mudam de formas de baixo peso molecular para formas de peso molecular mais alto. As células na parte superior do epitélio expressam genes que codificam uma variedade de proteínas especializadas que interagem com os filamentos intermediários de citoqueratina e com a membrana celular para produzir uma massa compacta, elástica e mecanicamente resistente (queratina). Nos pequenos grânulos de querato-hialina estão algumas destas proteínas especializadas, como a involucrina (Stevens \& Lowe, 2001).

Quando os queratinócitos chegam ao estrato espinhoso, eles se tornam permeáveis a íons cálcio que auxiliam a fazer ligação transversal da involucrina com 
outras proteínas, constituindo deste modo uma camada resistente. A camada espinhosa é constituída por grandes células poliédricas contendo delicadas tonofibrilas, são grandes e metabolicamente ativas (Junqueira, 1995). A camada granulosa apresenta células com pequenos grânulos de querato-hialina. $O$ estrato lúcido só aparece na pele espessa. E finalmente, a camada córnea forma uma superfície resistente da epiderme constituída por células degeneradas e sem núcleos, intimamente aderidas, carregadas de filamentos de queratina e com as membranas insolúveis pela deposição de uma escleroproteína filamentosa chamada involucrina (Junqueira, 1995).

Devido à citomorfose dos queratinócitos durante a migração da camada basal em direção à superfície, são identificadas cinco zonas morfologicamente distintas: basal, espinhoso, granuloso, lúcido (somente na pele espessa) e córneo (Gartner, 1997).

\subsection{CAMADAS DA EPIDERME}

\subsubsection{ESTRATO BASAL}

O estrato basal, ou estrato germinativo, é a camada mais profunda da epiderme e está sustentado pela lâmina basal, formando uma interface irregular com o tecido conjuntivo subjacente (derme). É constituída por uma única camada 
de células cúbicas a cilíndricas baixas, mitoticamente ativas, que contêm citoplasma basófilo e um núcleo grande. Muitos desmosomos estão localizados nos compartimentos laterais que ligam as células do estrato basal umas às outras e às células do estrato espinhoso. Os hemidesmosomos localizados na porção basal ligam os queratinócitos basais à lâmina basal. O processo de mitose é comum no estrato basal, e quando novas células são formadas, a camada superior de células migra em direção à superfície para constituir uma nova camada, o estrato espinhoso (Gartner \& Hiatt, 1999).

A proliferação das células na camada germinativa também forma as cristas epidérmicas, as quais se estendem para dentro da derme em desenvolvimento. Estas cristas começam a aparecer nos embriões com 10 semanas de vida intrauterina e estão completamente formadas em torno da 17ạ semana. (Persaud \& Moore, 2008).

\subsubsection{ESTRATO ESPINHOSO}

O estrato espinhoso é a camada mais espessa da epiderme e é constituído por queratinócitos de fenótipo poliédrico pavimentoso. Os queratinócitos localizados na porção inferior deste estrato são também mitoticamente ativos; dessa forma o estrato espinho e basal são responsáveis pela renovação dos queratinócitos epidérmicos (Stevens \& Lowe, 2001). Os queratinócitos do estrato 
espinhoso possuem as mesmas organelas do estrato basal. Entretanto, há mais feixes de filamentos intermediários (tonofilamentos), representando a citoqueratina. Estes feixes se dispõem a partir da região perinuclear, em direção aos processos celulares altamente interdigitados e que ligam células adjacentes umas às outras através dos desmosomos. Estes processos, denominados de pontes intercelulares, conferem às células uma aparência de célula espinhosa. À medida que os queratinócitos migram em direção a superfície, há produção contínua dos tonofilamentos, que se agrupam em feixes (tonofibrilas), tornando o citoplasma eosinófilo (Gartner \& Hiatt, 1997).

As células do estrato espinhoso também contêm grânulos secretores em seu citoplasma, chamados de grânulos lamelares. Estas vesículas achatadas abrigam substâncias de natureza lipídica, intimamente agrupadas (Gartner \& Hiatt, 1997).

\subsubsection{ESTRATO GRANULOSO}

O estrato granuloso característico consiste de três a cinco camadas de queratinócitos achatados. É a camada mais superficial da epiderme na qual as células ainda possuem núcleo. O citoplasma dos queratinócitos nesta camada possui grânulos de querato-hialina. Os filamentos de queratina estão associados com estes grânulos, com alguns filamentos que se entrelaçam (Gartner \& Hiatt, 1997). 
As células neste estrato apresentam maior número de grânulos revestidos por membrana do que as do estrato espinhoso. O conteúdo desses grânulos é liberado por exocitose, formando uma substância rica em lipídeos sobre as membranas plasmáticas (Gartner \& Hiatt, 1997).

\subsubsection{ESTRATO LÚCIDO}

O estrato lúcido é uma camada imediatamente acima do estrato granuloso. Está presente somente na pele espessa. Embora as células achatadas desse estrato não possuam organelas ou núcleos, elas contêm filamentos de queratina densamente agrupados, orientados paralelamente à superfície da pele, e eleidina, um produto da transformação da querato-hialina (Gartner \& Hiatt, 1997).

\subsubsection{ESTRATO CÓRNEO}

O estrato córneo é a camada mais superficial da pele. É constituído por numerosas camadas de células achatadas e completamente queratinizadas. As células que estão afastadas da superfície da pele mostram desmosomos, enquanto as células próximas à superfície da pele, chamadas de células escamosas ou 
cornificadas, não apresentam desmosomos e estão prestes a ser descamadas (Gartner \& Hiatt, 1997).

\subsection{POLARIDADE DAS CÉLULAS EPITELIAIS}

As células epiteliais apresentam dois domínios principais; um apical e outro basolateral. Cada domínio é definido por características estruturais e funcionais específicas. Por exemplo, o domínio apical tem importantes estruturas para a proteção da superfície epitelial, tais como cílios no trato intestinal, ou para absorção de substâncias (microvilos no epitélio intestinal) (Carvalho \& ReccoPimentel, 2001).

Os complexos juncionais e as moléculas de adesão celular estão presentes no domínio basolateral de modo a ancorar as células epiteliais umas às outras e à membrana celular (Carvalho \& Recco-Pimentel, 2001).

\subsection{PROCESSO DE DIFERENCIAÇÃO DOS QUERATINÓCITOS}

Os queratinócitos no estrato espinhoso têm um formato poligonal achatado e o citoplasma apresenta grânulos lamelares. Os feixes de filamentos intermediários 
(tonofibrilas) se estendem para o interior dos prolongamentos citoplasmáticos e se fixam na placa densa de desmosomo (Kierszenbaum, 2008).

A função principal dos filamentos intermediários é fornecer suporte mecânico para a célula. Os monômeros protéicos de filamentos intermediários são constituídos por três domínios: um domínio em formato de bastão (central), domínio de cabeça N-terminal não-helicoidal e um domínio de cauda C-terminal. Durante a polimerização, pares de dímeros, formados pelo alinhamento paralelo de monômeros, se associam em tetrâmeros em uma orientação lado a lado, porém antiparalela. Cerca de oito tetrâmeros se alinham extremidade com extremidade para formar um protofilamento. Pares de protofilamentos se associam lateralmente para formar uma protofibrila, e quatro protofibrilas, um total de oito protofilamentos, se enovelam para formar um filamento intermediário semelhante a uma corda. Cinco principais tipos de proteínas de filamentos intermediários foram identificadas com base na similaridade do bastão. Elas são referidas de I a V. O tipo I são queratinas ácidas e o tipo II são queratinas neutras e básicas. As queratinas de filamentos intermediários do tipo I e do tipo II formam tonofilamentos associados a moléculas presentes nas placas citoplasmáticas de desmossomas e hemidesmossomicas (Kierszenbaum, 2008; Moll, 1983).

Na epiderme da pele, as células basais expressam as citoqueratinas 5 e 14 . As células em diferenciação nas camadas superiores expressam citoqueratinas 1 e 10. Em algumas regiões da epiderme, tais como a região da palma e plantas, encontra-se a citoqueratina 9. Mutações nas citoqueratinas 5 e 14 causam doenças 
bolhosas hereditárias da pele que pertencem ao tipo clínico caracterizado como epidermólise bolhosa simples. (Kierszenbaum, 2008; Moll, 1983).

O estrato granuloso é constituído por queratinócitos nucleados achatados com grânulos de querato-hialina. Os grânulos lamelares, que primeiramente aparecem nos queratinócitos do estrato espinhoso, aumentam em quantidade no estrato granuloso, e o produto lamelar, o glicolipídeo acilglicosilceramida, é liberado nos espaços intercelulares. No espaço intercelular, o material lipídico lamelar forma uma estrutura com multicamadas, organizada em lâminas espessas, cobrindo a superfície dos queratinócitos da camada superior, o estrato lúcido. A cobertura glicolipídica proporciona a formação da barreira impermeável da epiderme (Kierszenbaum, 2008).

O estrato lúcido e o estrato córneo possuem o citoplasma com agregados de filamentos intermediários de queratina, unidos por ligações cruzadas com filagrina. A filagrina se agrega aos filamentos intermediários de queratina em feixes compactados, levando ao achatamento celular. O complexo de queratina-filagrina é depositado na face interna da membrana plasmática, formando uma estrutura chamada de envoltório celular corneificado. Proteínas adicionais (involucrina, pequenas proteínas ricas em prolina e loricrina) são unidas e reforçam o envoltório celular corneificado imediatamente abaixo da membrana plasmática. $\mathrm{Na}$ face exterior, um complexo de lipídeos liberado por grânulos lamelares se une ao envoltório celular, formando o complexo do envoltório celular corneificado composto (Kierszenbaum, 2008). 


\subsection{MEMBRANA BASAL}

A membrana basal é constituída por dois componentes: a lâmina basal e a lamina reticular.

\subsubsection{LÂMINA BASAL}

A lâmina basal corresponde a uma estrutura que divide o contato entre as células epiteliais e o tecido conjuntivo subjacente. É um tipo especializado de matriz extracelular que resulta da auto-organização de moléculas de laminina com colágeno do tipo IV, entactina e proteoglicanos e numerosas moléculas de adesão (Junqueira \& Carneiro, 2004; Kierszenbaum, 2008).

A lâmina basal se prende ao tecido conjuntivo por meio de fibrilas de ancoragem constituídas por colágeno do tipo VII (Junqueira \& Carneiro, 2004).

A lâmina basal tem múltiplas funções que incluem um papel estrutural e na filtração de moléculas, determinação da polaridade das células, regulação da proliferação e a diferenciação celular, ligando-se com fatores de crescimento, influíencia no metabolismo celular e organização das proteínas nas membranas 
plasmáticas de células adjacentes, afetando a transdução de sinais através destas membranas (Junqueira \& Carneiro, 2004).

É constituída por duas regiões; a lâmina lúcida e a lâmina densa. A lâmina lúcida consiste principalmente nas glicoproteínas extracelulares laminina, entactina, distroglicanos e integrinas. A lâmina densa compreende uma trama de colágeno tipo IV, a qual é recoberta tanto do lado da lâmina lúcida quanto do lado da lâmina reticular, pelo proteoglicano perlecano (ou perlecan). As cadeias laterais de heparan-sulfato que se projetam da proteína central do perlecano formam um poliânion. A face da lâmina densa voltada para a lâmina reticular também possui fibronectina (Cooper, 2002).

\subsubsection{LÂMINA RETICULAR}

A lâmina reticular é um componente derivado do tecido conjuntivo e é responsável pela fixação da lâmina densa ao tecido conjuntivo subjacente (Cooper, 2002).

É formada por fibras colágenas e confere sustentação à lâmina basal (Kierszenbaum, 2008), É uma região de espessura variável que apresenta fibroblastos e colágenos do tipo I e III; a sua espessura modifica-se conforme a quantidade de força de fricção do epitélio sobrejacente. As fibras colágenas dos tipos I e III do tecido conjuntivo, formam alças na lâmina reticular, onde elas 
interagem e estão ligadas às microfibrilas e fibrila de ancoragem da lâmina reticular (Cooper, 2002).

\subsection{JUNÇÕES CELULARES}

As células dentro de um tecido estão interconectadas com outras células e com a matriz extracelular através de estruturas especializadas da membrana plasmática, denominadas junções intercelulares e junções célula-matriz, respectivamente. Estruturalmente, as junções intercelulares são classificadas em quatro diferentes componentes: Junção de oclusão, junção aderente, desmosomo e junção comunicante (Carvalho \& Recco-Pimentel, 2001).

Quanto às junções célula-matriz, estas podem ser divididas em dois tipos: a junção de adesão focal e o hemidesmosomo (Carvalho \& Recco-Pimentel, 2001).

Na pele, as principais estruturas adesivas são as junções de ancoragem e as junções aderentes.

As junções de ancoragem estão envolvidas primariamente com a adesão celular. Elas podem ser divididas segundo a morfologia, expressão de componentes transmembrânicos e de acordo com a associação com os filamentos do citoesqueleto. Desmosomos e hemidesmosomos conectam-se aos filamentos de citoqueratinas enquanto que a junções aderentes e os contatos focais estão ligadas aos microfilamentos de actina. As caderinas e as integrinas são moléculas que, 
juntamente com outras, participam da estrutura das junções de ancoragem (Cozzani et al, 2001).

\subsubsection{JUNÇÕES INTERCELULARES}

\subsubsection{JUNÇÕES DE ANCORAGEM}

As junções de ancoragem são encontradas abaixo das junções de oclusão, normalmente próximas à superfície apical de um epitélio. Há três classes: zônula de adesão (zonula adherens) ou desmosomo em cinturão, mácula de adesão (macula adherens) ou desmosomo em ponto ou em mancha, e o hemidesmosomo (Kierszenbaum, 2008).

De modo similar às junções de oclusão, a zônula de adesão é uma junção semelhante a um cinturão. Está associada a microfilamentos de actina. Essa interação é mediada pela interação de caderinas (desmocolinas e desmogleínas)

com cateninas (alfa, beta e gama). As principais desmogleínas expressas na epiderme da pele são a desmogleína 1 e a desmogleína 3 (Kierszenbaum, 2008). 
A mácula de adesão (ou desmosomo) é uma junção semelhante a uma mancha, associada a filamentos intermediários de citoqueratinas (tonofilamentos, que se estendem de um desmosomo a outro nas superfícies laterais e basais (neste caso, hemidesmosomos) das células epiteliais. Esses desmosomos conferem resistência e rigidez a camada de células epiteliais. Em contraste com as junções de oclusão, as membranas plasmáticas adjacentes unidas por uma zônula de adesão estão separadas por um espaço intercelular relativamente amplo. Este espaço está ocupado pela porção glicosilada de proteínas da família caderinas, demogleínas e desmocolinas, ancoradas a placas citoplasmáticas contendo desmoplaquina, placoglobina e placofilina. As placas citoplasmáticas estão aderidas à face citosólica da membrana plasmática. $\mathrm{O}$ entrelaçamento de caderinas similares mantém duas células unidas através de interações homofílicas ou heterofílicas cálcio-dependentes (Kierszenbaum, 2008).

\subsubsection{JUNÇÕES CÉLULA-MATRIZ}

\subsubsection{JUNÇÃO DE ADESÃO FOCAL}

A célula interage com a matriz extracelular e se adere a ela por meio de proteínas integrais denominadas integrinas (Carvalho \& Recco-Pimentel, 2001). 
A função adesiva da adesão focal pode ser regulada durante os processos celulares (por exemplo, migração e divisão celular) e sob condições experimentais. (Carvalho \& Recco-Pimentel, 2001).

\subsubsection{HEMIDESMOSOMOS}

Os hemidesmossomos são estruturas assimétricas que ancoram o domínio basal de uma célula epitelial à lâmina basal subjacente. Eles são constituídos pelas seguintes porções: um disco citoplasmático interno associado a filamentos intermediários de citoqueratinas, e uma placa membranar externa que liga o hemidesmossoma à lâmina basal através de filamentos de ancoragem (composto de laminina 5) e da integrina alfa6/beta4. Os hemidesmossomas aumentam a estabilidade total dos tecidos epiteliais através da ligação de filamentos intermediários do citoesqueleto aos componentes da lâmina basal (Kierszenbaum, 2008).

\subsection{A PELE E ESTRUTURAS DE ADESÃO}

Fenômenos biológicos e fisiológicos vitais tais como a embriogênese, proliferação, diferenciação e morte celular são orquestrados por um complexo 
sistema de moléculas e receptores de adesão. Essas moléculas e receptores são importantes para a manutenção da integridade da pele, desde os estágios mais precoces do período embrionário, onde desmosomos são detectados (5 a 6 semanas de vida gestacional) (Hentula et al, 2001). Essas moléculas estão também envolvidas na definição da estrutura e arquitetura da pele, no controle da polarização celular e em uma cascata complexa de sinalização de controla os níveis de maturação celular (Marchisio et al, 1997; Hotchin et al, 1995).

A adesão celular é crucial para o agrupamento de células em estruturas tridimensionais que formam os tecidos animais, estabelecendo relações entre as células e o seu meio ambiente, juntamente com suas conexões internas com o citoesqueleto, determinando assim, a arquitetura dos diversos tecidos (Gumbiner, 1996).

A adesão intercelular e células/ matriz extracelular é mediada por proteínas de membrana denominadas moléculas de adesão celular, que podem ser divididas em quatro grandes grupos: as selectinas, as integrinas, a superfamília das imunoglobulinas e as caderinas. As adesões celulares mediadas pelas selectinas, integrinas e caderinas requerem $\mathrm{Ca}++$ ou $\mathrm{Mg}++$ (Cooper, 2002). Essas moléculas se localizam ao nível da membrana basal.

Como todas as proteínas transmembrana, sua estrutura é composta de um domínio extracelular responsável pela adesão ao ligante, de um ou vários domínios hidrófobos transmembrana e de um domínio citoplasmático, que será responsável 
pelos efeitos celulares (chamado domínio responsável pela transdução do sinal) como, por exemplo, modificações da expressão gênica.

Há 4 famílias responsáveis pelos fenômenos de adesão. Uma única família é responsável pelos mecanismos de adesão entre célula e matriz; a família das integrinas. Três famílias respondem pelos fenômenos de adesão intercelular; a família das caderinas, a superfamília das imunoglobulinas e a família das selectinas (Catala, 2003).

As caderinas são moléculas de adesão que participam de forma crítica do desenvolvimento embrionário de vários tecidos, incluindo a pele. A superfamília das caderinas é composta por pelo menos 80 moléculas, incluindo as caderinas clássicas, desmogleínas e desmocolinas, entre outras. Essas moléculas estão envolvidas na adesão intercelular de forma homotípica (Andreoli, 1999).

Todos os membros dessa família são moléculas transmembrânicas dependentes de Ca2+ no seu sítio de ligação. O Ca2+ é crítico para a função da molécula, servindo também para a manutenção estrutural da caderina. Sua cauda citoplasmática é altamente conservada e serve de elo com o citoesqueleto através de ligações específicas com as moléculas $\alpha$ e $\beta$ catenina (Yagi \& Takeichi, 2000; Hynes, 1999). O Complexo das cateninas tem, pelo menos, três funções distintas associadas ao papel das caderinas; as caderinas medeiam uma ligação direta aos filamentos de actina, elas interagem com moléculas reguladoras do citoesqueleto de actina, e elas controlam o caráter adesivo do domínio extracelular das caderinas. A Associação da actina ao complexo caderina-catenina é essencial à morfogênese 
celular, a mudanças no formato celular, e ao estabelecimento da polaridade celular (Kierszenbaum, 2008).

As caderinas mais relevantes presentes no epitélio cutâneo e seus anexos são:

- Caderinas clássicas que compreende as caderinas $E, P$ e $N$, entre outras;

- Caderinas desmosômicas, que fazem parte da estrutura dos desmosomos - desmocolinas e desmogleínas.

A E-caderina é um dos principais elos na adesão de células epiteliais (Takeichi, 1990). Trata-se de uma glicoproteína transmembrânica de 120 kD, presente em todo o epitélio e que possui seu gene mapeado no cromossomo 16q.22.2 (Takeichi, 1991). Essa caderina está localizada principalmente nas zônulas de aderência juncional, sendo responsável por uma firme adesão célula-célula (Pignatelli \& El-Bahrawy, 1998). A expressão contínua da E-caderina é fundamental para a manutenção do epitélio como tecido. Na sua ausência, as demais moléculas de adesão existentes nesse tecido são incapazes de manter tal estrutura. (Gumbiner, 1996). Para exercer suas funções, a E-caderina depende da formação de complexos citoplasmáticos que por sua vez participam as transdução de sinais que regulam o fenótipo celular desde o desenvolvimento (Gumbiner, 1996).

A N-caderina é encontrada no sistema nervoso central, no cristalino (lente) do olho, e em células musculares esqueléticas e cardíacas (Kierszenbaum, 2008). 
A P-caderina foi detectada primeiramente nas camadas extra-embrionárias do embrião precoce, como no cone ectoplacental e endoderme visceral, no estágio de implantação. A P-caderina está relacionada com as camadas proliferativas dos tecidos embrionários (Pignatelli \& Bahrawy, 1998).

Estudos relatam a participação dessas caderinas no desenvolvimento embrionário e na manutenção de tecidos adultos. No embrião em desenvolvimento a adesão intercelular caderina-caderina pode ter um efeito positivo na divisão celular, colaborando para o correto agrupamento e crescimento celular e desenvolvimento dos tecidos (Vleminckx \& Kemler, 1999).

Em fetos humanos, a E-caderina é observada nas células mais superficiais do epitélio, bem como durante o desenvolvimento dos anexos cutâneos (Furukawa et al, 1997). A P-caderina é expressa somente nas células basais do epitélio e nas camadas mais externas dos anexos cutâneos. É associada a compartimentos proliferativos desses tecidos (Furukawa et al, 1997; Fujita et al, 1992).

Estudos laboratoriais com animais "knock-out" e cultivo celular demonstraram que a falta das caderinas, especialmente a E-caderina é letal, impedindo que o embrião se desenvolva além da fase de blastocisto.

É provável que um conhecimento de como esta classe de moléculas funciona durante o desenvolvimento normal dará indicações importantes sobre a gênese de muitos defeitos de nascimento induzidos por causas genéticas ou ambientais. Aproximadamente 20 caderinas clássicas têm sido identificadas. 
A descrição de modo resumido das moléculas e E- e P-caderina pode ser observada no Quadro 2.

Quadro 2- Descrição e distribuição das caderinas

\begin{tabular}{|c|c|c|c|}
\hline MOLÉCULAS & $\begin{array}{l}\text { MECANISMO } \\
\text { DE LIGAÇÃO }\end{array}$ & $\begin{array}{c}\text { DEPENDÊNCIA DE } \\
\text { ÍON }\end{array}$ & DISTRIBUIÇÃO NOS TECIDOS \\
\hline E-caderina & HOMÓFILO & Ca++ dependente & $\begin{array}{l}\text { Inicial: Massa celular interna, trofoblasto } \\
\text { Tardio: Ectoderma não neural, epitélio urogenital } \\
\text { (ducto mesonéfrico, ducto paramesonéfrico), epitélios } \\
\text { do aparelho digestivo (fígado, pâncreas), epitélios do } \\
\text { aprelho rsepiratório, glândulas faríngeas }\end{array}$ \\
\hline P-caderina & HOMÓFILO & $\mathrm{Ca}++$ dependente & $\begin{array}{l}\text { Inicial: Ectoderma extra-embrionário, endoderma, } \\
\text { notocorda, mesoderma da placa lateral } \\
\text { Tardio: Epiderme, camada pigmentar da retina, } \\
\text { placenta }\end{array}$ \\
\hline \multicolumn{4}{|c|}{ Homófilo: Ligação a células do mesmo tipo } \\
\hline
\end{tabular}

A participação das caderinas vem também sendo estudada em diversas doenças: nas neoplasias de origem epitelial, sua expressão é diminuída ou ausente, estando relacionada à perda da arquitetura tecidual normal e a fenótipos carcinogênicos. Nas doenças vésico-bolhosas da pele como pênfigo vulgar, a destruição das caderinas por auto-anticorpos causa perda da adesão das células epiteliais, causando bolhas e ulceração cutânea (Andreoli, 1999). 
A perda de caderinas também está associada à aquisição de um comportamento invasivo por células tumorais (metástases) (Kierszenbaum, 2008).

Portanto, fica evidente que o estudo das caderinas é essencial dada a sua importância na fisiologia e patologia da pele e seus anexos.

A segunda família de moléculas de adesão importante na fisiologia da pele é a das integrinas, que constituem a principal família de receptores que intermedeiam interações entre células e matriz extracelular, influenciando direta ou indiretamente numerosos aspectos do comportamento celular - adesão e migração, proliferação e diferenciação (De Arcangelis \& Georges-Labouesse, 2000).

Integrinas são heterodímeros transmembrânicos compostos por duas subunidades $-\alpha$ (alfa) e $\beta$ (beta) que estão ligadas de forma não covalente e dependente de cátions bivalentes (Hynes, 1992). Cada subunidade é composta de domínios extra-citoplasmáticos grandes, de uma porção transmembrânica e de uma cauda citoplasmática curta (exceto a subunidade $\beta 4$ ). Mais de 20 heterodímeros de integrinas já foram identificados e estes reconhecem componentes da matriz extracelular, bem como outros ligantes do meio e da superfície de outras células, por meio de sua porção extra-citoplasmática (Hynes, 1992; Beauvais-Jouneau \& Thierry, 1997). As integrinas agrupam-se em áreas determinadas adesões focais, onde sua porção intracitoplasmática mantém contato com o citoesqueleto. Desta forma, essas moléculas proporcionam um canal de comunicação entre o meio extracelular e intracelular, ativando vias de sinalização que irão influenciar o comportamento celular (Giancotti \& Ruoslahti, 1999). 
No meio extracelular, as integrinas servem primariamente como receptores de colágeno, laminina e fibronectina. Cada integrina reconhece mais de um ligante e vice-versa. Entretanto, as interações com ligantes distintos irão ativar vias de sinalização específicas no meio intracelular (Heino, 2000). Essa capacidade de reconhecimento está relacionada à presença da seqüência tripeptídica Arg-Gly-Asp (RDG) no substrato (Darribère et al, 2000).

No meio intracelular, o domínio citoplasmático das integrinas interage com as proteínas do citoesqueleto- $\alpha$-actinina, talina, filamina, promovendo vias de transdução de sinais que envolvem pp125FAK, caveolina, "integrin-linked kinases" ou ILKs e o receptor para proteína kinase C ativada (Rack1) (Hemler, 1998). Adicionalmente, o domínio citoplasmático das integrinas interage com as proteínas regulatórias paxilina, calreticulina, citoesinas, endonexinas e ICAP, que podem modificar a afinidade das integrinas pelos seus receptores extra-celulares (Darribère et al, 2000).

Dada a importância das integrinas e de sua participação em processos biológicos, numerosos estudos vem sendo realizados no sentido de elucidar a distribuição e compreender as funções dessas moléculas durante o desenvolvimento.

As integrinas estão envolvidas no processo de fertilização, promovendo a adesão sperm-oócito, gastrulação, implantação do blastocisto e formação da placenta (Darribère et al, 2000). 
Na organogênese, as integrinas têm se mostrado importantes na formação do sistema nervoso central dos vertebrados, com séries de eventos indutivos complexos e re-arranjos teciduais que produzem o tubo neural. A partir disso a crista neural é formada a partir do tubo neural dorsal e migra ao longo da matriz extracelular rica em fibronectina, laminina, vitronectina, colágeno e tenascina (Darribère et al, 2000; Dufour et al, 1998).

A associação entre a integrina e seus ligantes é mais fraca do que a entre um receptor e seu ligante. As integrinas são muito mais numerosas do que os receptores, compensando assim, a fraqueza das ligações e permitindo também a migração das células ao longo da superfície da matriz extracelular (Junqueira \& Carneiro, 2000).

Durante os processos de miogênese, importante expressão de integrinas tem sido relatada. Sua expressão é freqüentemente diminuída após a completa diferenciação muscular, já no embrião adulto (Sastry et al, 1996). A presença de integrinas também é relatada nos processos de vasculogênese e angiogênese (Drake et al, 1995; Hammes et al, 1996).

A morfogênese tubular, que leva a formação da traquéia e bronquíolos distais durante o desenvolvimento fetal, também depende das interações entre integrinas e matriz extracelular, sendo essas interações as responsáveis pela modulação da migração das células epiteliais nesse processo (Coraux et al, 2000).

$\mathrm{Na}$ mucosa gástrica em desenvolvimento, a expressão coordenada de integrinas $\alpha 2$ e $\alpha 3$ e a re-distribuição celular da integrina $\alpha 2 \beta 1$ parece representar 
eventos-chave na diferenciação das glândulas secretórias, especialmente células responsáveis pela síntese e secreção de enzimas digestivas (Chénard et al, 2000).

O envolvimento das integrinas também é relatado no controle da proliferação, apoptose, diferenciação e manutenção da polaridade baso-apical de células epiteliais mamárias. Portanto é tida como fator essencial para o desenvolvimento e função da glândula mamária normal (Faraldo et al, 1998).

Mais recentemente, as moléculas de adesão vêm sendo consideradas como importante elo na cadeia de transdução de sinais, participando de fenômenos proliferativos e de diferenciação celular, e, principalmente na pele, auxiliando na manutenção da polaridade celular e arquitetura tecidual.

Em especial, a integrina $\beta 1$ tem sido intimamente relacionada à diferenciação e agrupamento dos queratinócitos para a formação da epiderme. A integrina $\beta 1$ tem ainda sido estudada como marcador de células-tronco, proporcionando assim, uma forma de distingui-las das populações de células proliferativas (Bagutti et al, 2001).

Alicerçados na literatura vigente, que mostra a importâncias de fenômenos de interação intercelular e entre célula e a matriz-extracelular, o presente trabalho investiga os aspectos básicos das estruturas adesivas da pele humana presentes durante o desenvolvimento embrionário e sua relação com a diferenciação dos queratinócitos, evidenciada pela expressão de citoqueratinas e involucrina durante sua maturação. 


\section{MATERIAL E MÉTODO}

Fragmentos de pele derivados de embriões/ fetos humanos em diferentes estágios gestacionais ( $4-24$ semanas) foram utilizados. Todos os fetos pesavam menos que 500 gramas, sendo considerados peças cirúrgicas. Esse material foi cedido pelo Departamento de Patologia do Hospital das Clínicas da Faculdade de Medicina da Universidade de São Paulo e pelo Serviço de Verificação de Óbito de São Paulo, da Faculdade de Medicina da Universidade de São Paulo. Fetos provenientes de abortos devido a aberrações genéticas foram excluídos. Subprojeto foi submetido ao Comitê de Ética em Pesquisa da Faculdade de Medicina da Universidade de São Paulo. As estimativas da idade de embriões são estabelecidas pelas suas características externas e pela medida de seu comprimento. Isoladamente, o tamanho pode ser um critério não confiável, pois a velocidade de crescimento de alguns embriões diminui progressivamente antes da morte. No início da quarta semana de vida intrauterina, os embriões são "retos", por isso, a sua medida indica o maior comprimento (GL, greatest length). A altura sentado ( $\mathrm{CRI}$, rump length), ou vérticenádegas, é usado com maior freqüência em embriões mais desenvolvidos. O comprimento do pé (CHL, crown heel length), ou vértice-calcanhar, é algumas vezes, usado para medir embriões com oito semanas de idade (Persaud \& Moore, 2008). Neste estudo foi realizada a estimada pelo comprimento do pé, pois o fetos já estavam fixados em formol e alguns com algumas mutilações.

A descrição mais detalhada dos fetos estudados esta demonstrada no Quadro3. 
Quadro 3 - Descrição dos embriões/ fetos estudados

\begin{tabular}{|c|c|c|c|}
\hline FETOS & $\begin{array}{c}\text { COMPRIMENTO } \\
\text { (cm) }\end{array}$ & $\begin{array}{c}\text { IDADE } \\
\text { (SEMANAS) }\end{array}$ & ESPÉCIMES \\
\hline 1 & Menos que 0,5 & 4 & Dorso, genital, couro cabeludo, planta e palma \\
\hline 2 & 0,5 & 8 & Mão, pé, dorso e genital \\
\hline 3 & 1,7 & 14 & $\begin{array}{c}\text { Couro cabeludo, coxa, dorso, planta, palma, } \\
\text { dígito, antebraço pálpebra e sobrancelha. }\end{array}$ \\
\hline 4 & 2,1 & 16 & $\begin{array}{c}\text { Couro cabeludo, braço, coxa, dorso, planta, } \\
\text { palma, dígito, face, pálpebra e sobrancelha e } \\
\text { genital }\end{array}$ \\
\hline 7 & 3,0 & 19 & $\begin{array}{c}\text { Couro cabeludo, antebraço, coxa, dorso, planta, } \\
\text { palma, dígito, face, pálpebra e sobrancelha e } \\
\text { genital }\end{array}$ \\
\hline 6 & 3,5 & 24 & $\begin{array}{c}\text { Couro cabeludo, palma, planta, pálpebra e } \\
\text { sobrancelha, dorso, antebraço e genital }\end{array}$ \\
\hline & & 24 couro cabeludo, face, pálpebra e sobrancelha e genital \\
\hline
\end{tabular}

Os fragmentos de pele dissecados foram fixados em formol a $10 \%$. Para a realização da etapa imunoistoquímica, os fragmentos fixados foram processados histologicamente em autotécnico e incluídos em parafina. 
Os blocos de parafina contendo os espécimes foram cortados a uma espessura de $5 \mu \mathrm{m}$ e corados em hematoxilina e eosina para avaliação da morfologia presente. Fragmentos de $3 \mu \mathrm{m}$ foram cortados para a realização da técnica imunoistoquímica, cujo protocolo é descrito a seguir:

Os cortes de $3 \mu \mathrm{m}$ foram desparafinizados e diafanizados em dois banhos de xilol: o primeiro a $60^{\circ} \mathrm{C}$ por 30 minutos e o segundo à temperatura ambiente por 20 minutos. $A$ seguir os cortes foram re-hidratados em cadeia descendente de etanol $(100 \%, 95 \%, 85 \%$, respectivamente) e imersos em solução de hidróxido de amônia a 10\% durante 10 minutos para a remoção de pigmentos formólicos.

Recuperação dos sítios antigênicos ocorreu de várias formas dependendo do anticorpo primário utilizado (Quadro 4).

Após a lavagem em água corrente e água destilada, incubação do material em solução de peróxido de hidrogênio 20 volumes por 10 minutos com o intuito de se bloquear a peroxidase endógena tecidual foi realizada.

Repetida a lavagem com água corrente e água destilada, os cortes foram imersos duas vezes em solução de TRIS pH 7,4, por dois minutos cada. Em seguida, os cortes foram incubados com solução de 0,5\% BSA (Sigma), 2,5\% SFB (Cultilab) em TRIS, pH 7,4, por 60 minutos, a fim de se bloquear reações do soro primário com proteínas inespecíficas teciduais.

Em seguida, os cortes foram incubados com o soro primário diluído em solução de $1 \%$ BSA (Sigma) em TRIS pH7,4. Informações sobre os anticorpos e etapas específicas do protocolo são descritas no Quadro 4. 
Os procedimentos posteriores foram sempre precedidos lavagens no tampão TRIS pH 7,4, durante 5 minutos ou em água corrente por 10 minutos.

Após a incubação com o anticorpo primário, os espécimes foram incubados com o reagente En Vision (Dako) que é um sistema de anticorpo livre de biotina.

Para a reação de revelação, os espécimes foram incubados durante 3 minutos na solução contendo agente cromogênico diaminobenzidina - DAB (Sigma) na concentração de $60 \mathrm{mg}$ em $100 \mathrm{ml}$ de PBS $0,01 \mathrm{M}$ pH 7,40, ativada por $1000 \mu \mathrm{l}$ peróxido de hidrogênio 20 volumes.

Os cortes histológicos foram então lavados em água corrente e água destilada e contra-corados com Hematoxilina de Carazzi.

Posteriormente, os cortes foram desidratados em cadeia ascendente de álcoois, diafanizados em três banhos de xilol, e montados em resina permount para o exame ao microscópio de luz.

Controles negativos das reações supracitadas foram realizados através da incubação de espécimes com soro não-imune.

Os resultados obtidos nas reações imunoistoquímicas foram analisados por dois observadores e tabulados de forma qualitativa. Todos os resultados foram registrados pelo sistema de fotomicrografia digital (Microscópio Olympus BX41 e câmera Olympus Evolt E-330). 
Quadro 4-Anticorpos monoclonais utilizados e peculiaridades do protocolo

\begin{tabular}{|c|c|c|c|c|c|}
\hline ANTICORPO & CLONE & EMPRESA & RECUPERAÇÃO ANTIGÊNICA & DILUIÇÃO & INCUBAÇÃO \\
\hline E- Caderina & $36 b 5$ & Novo Castra & microondas & $1: 25$ & "overnight" \\
\hline P-Caderina & $56 C 1$ & Novo Castra & câmara de pressão & $1: 25$ & "overnight" \\
\hline Citoqueratina 10 & DE-K10 & Dako & microondas & $1: 50$ & "overnight" \\
\hline Citoqueratina 14 & $A B-1$ & Neomakers & microondas & $1: 40$ & "overnight" \\
\hline Involucrina & Sy5 & Novo Castra & microondas & $1: 400$ & "overnight" \\
\hline $\begin{array}{l}\text { Integrina } \\
\text { Beta } 1\end{array}$ & $6 S 6$ & Chemicon & estufa a $37^{\circ} \mathrm{C}$ & $1: 100$ & "overnight" \\
\hline $\begin{array}{l}\text { Integrina } \\
\text { Beta } 4\end{array}$ & ELF-1 & Novo Castra & stemear & $1: 25$ & "overnight" \\
\hline
\end{tabular}

Todas as reações de imunoistoquímica foram realizadas paralelamente com tecidos adultos como controles negativo/positivo para uma melhor adequação da técnica e avaliação correta dos resultados obtidos. 
5 RESULTADOS 


\section{RESULTADOS}

\subsection{ANÁLISE MORFOLÓGICA}

A análise morfológica dos espécimes de pele dissecados dos embriões/ fetos humanos incluídos em nosso estudo revelou variações nos estágios de maturação da pele, bem como variações regionais na estrutura da epiderme. Os locais dissecados incluíram face, pálpebra/sobrancelha, couro cabeludo, palma, dígito, planta, genital, dorso, antebraço, coxa e genital de embriões/ fetos nos estágios gestacionais entre 4 e 24 semanas de vida intrauterina. De forma resumida esses aspectos são descritos a seguir e exemplos morfológicos ilustrados na Figura 1:

\subsubsection{O revestimento epitelial}

Nos embriões/ fetos mais precoces observou-se revestimento epitelial ainda rudimentar consistindo primordialmente de um epitélio de duas a três camadas de queratinócitos de citoplasmas claros. Nesses espécimes o tecido conjuntivo subjacente (derme) mostrou arranjo frouxo e desprovido dos anexos cutâneos. Em algumas regiões (pele da face, palmas e plantas) observou-se um epitélio exibindo maior número de camadas de queratinócitos e áreas focais onde se pôde notar proliferação na região da camada basal invadindo a derme subjacente - início da formação dos anexos cutâneos. 
Nos embriões/ fetos mais maduros, o revestimento epitelial consistiu de múltiplas camadas de queratinócitos com regiões já bem determinadas (camada basal, estrato intermediário e início de camada granulosa). Nessa fase a presença de anexos cutâneos rudimentares em várias fases de sua maturação foi evidente na derme. A camada granulosa foi mais evidente em algumas regiões especializadas como palmas e plantas. Apenas nos embriões/fetos mais desenvolvidos pôde notar a presença de camada queratinizada. 
Figura 1: Exemplos morfológicos dos aspectos da pele humana em diferentes fases do desenvolvimento fetal.
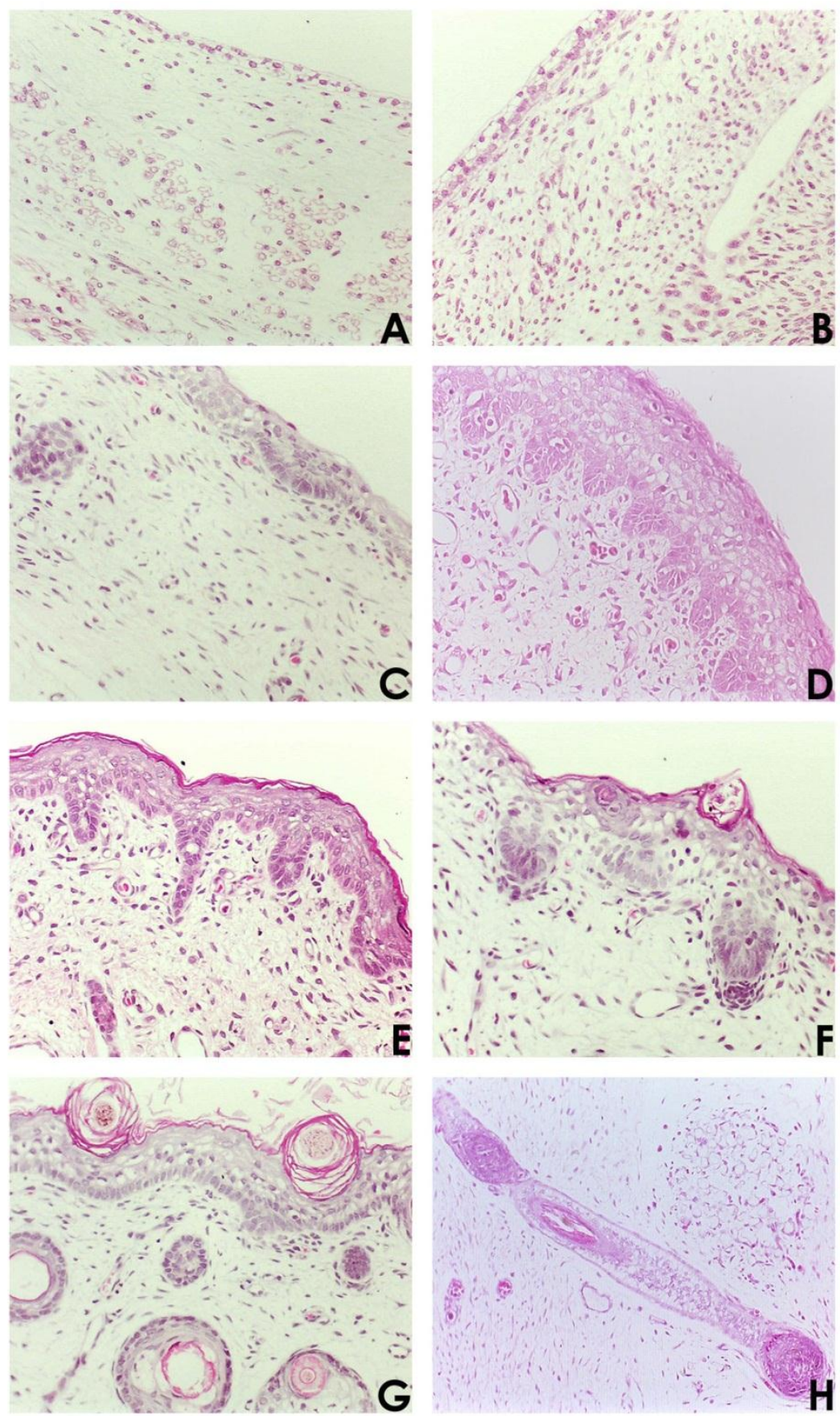
Legendas da Figura 1

A: Fragmento de pele exibindo revestimento epitelial ainda na fase de periderme (Hematoxilina e eosina, aumento original X 100).

B: Estágio inicial do desenvolvimento da epiderme mostrando revestimento epitelial de poucas camadas (três camadas de queratinócitos) (Hematoxilina e eosina, aumento original $\mathrm{X} 100)$.

C: Área de proliferação da camada basal que "mergulha" no tecido conjuntivo (Hematoxilina e eosina, aumento X 100).

D: Fragmento de pele da mucosa genital em estágio mais avançado de sua maturação exibindo prolongamentos epiteliais, camada espinhosa bem marcada (hematoxilina e eosina, aumento original $\mathrm{X} 100)$.

E: Fragmento de pele da palma mostrando camada córnea bem formada (hematoxilina e eosina, aumento original $\times 100)$.

F: Fragmento de pele da pálpebra mostrando camada córnea bem desenvolvida e rudimentos de anexos cutâneos (hematoxilina e eosina, aumento original X 100). 
G: Fragmento de pele do couro cabeludo mostrando camada córnea bem formada e anexos cutâneos (pêlos) em vários estágios de diferenciação (hematoxilina e eosina, aumento original X 100).

H: Corte longitudinal de folículo piloso em fase intermediária de sua diferenciação, na qual ainda não se evidenciam os anexos do pelo. Fragmento de pele da pálpebra mostrando camada córnea bem formada e rudimentos de anexos cutâneos (Hematoxilina e eosina, aumento original $\mathrm{X} 100)$. 


\subsection{ANÁLISE IMUNOISTOQUÍMICA}

Os resultados da análise imunoistoquímica realizada nos espécimes dissecados é descrita a seguir:

\subsubsection{CITOQUERATINA 14 (CK14)}

A citoqueratina 14 foi observada em toda extensão da camada basal, tanto da epiderme como da mucosa genital. Somente nos fetos mais precoces que apresentavam a periderme como estrutura de revestimento, a CK14 não foi encontrada. Em locais onde se observou atividade de proliferação celular, a CK14 estava ausente.

\subsubsection{CITOQUERATINA 10 (CK 10)}

A expressão da CK 10 foi uniforme na periderme. Na mucosa genital e nas camadas supra-basais da epiderme de estágios mais avançados da vida intrauterina, a CK10 estava presente nas camadas supra-basais. 


\subsubsection{INVOLUCRINA}

A expressão da involucrina foi observada em raras células na periderme dos fetos mais precoces (entre 11 e 14 semanas de vida intrauterina), nas diversas regiões estudadas. Em fetos mais desenvolvidos, com idade estimada entre 18 e 24 semanas de vida intrauterina, a epiderme já se apresentava bem estratificada e com evidências morfológicas de queratinização. Nesses espécimes, a involucrina foi observada nas camadas intermediária e superficial (corneificada) da epiderme.

\subsubsection{E-Caderina}

A Expressão da E-caderina foi uniforme em todas as camadas da epiderme, e localizada na membrana celular (contornando as membranas plasmáticas). Em regiões que apresentavam invaginações epiteliais mais profundas, a expressão da proteína encontravase diminuída ou ausente.

\subsubsection{P-Caderina}

A P-caderina foi positiva na epiderme, principalmente na camada basal e nas invaginações da epiderme. Em fetos mais desenvolvidos, a P-cad foi bem expressada na epiderme. 


\subsubsection{Integrina $\beta 1$}

A expressão da proteína $\beta 1$ foi intensa nas camadas mais superficiais e ausente na camada basal da epiderme. Além da epiderme, a mucosa genital e a periderme também expressaram a proteína.

\subsubsection{Integrina $\beta 4$}

A proteína Integrina $\beta 4$ foi observada nas diversas camadas da epiderme, mucosa genital (menos na camada basal) e na periderme. Nos espécimes de pele mais desenvolvidos notava-se expressão significativa desta proteína na camada basal dos queratinócitos em padrão bipolar.

A presença das integrinas, caderina, citoqueratinas e involucrina nas diferentes camadas epiteliais estão descritas no Quadro 5 e ilustrada nas Figuras 2, 3 e 4. 
Quadro 5- Distribuição das caderinas, integrinas, citoqueratinas e involucrinas nas diferentes camadas epiteliais em desenvolvimento intrauterino

\begin{tabular}{|c|c|c|}
\hline 8 semanas & 12 semanas & $\begin{array}{l}\text { 24 semanas } \\
\text { Estrato corneificado: INV }\end{array}$ \\
\hline $\begin{array}{l}\text { Periderme: integrina beta-1 } \\
\text { e beta-4, E-caderina (fraca), } \\
\qquad \text { CK } 10 \\
\text { Camda basal: integrina } \\
\text { beta-1 e beta-4 (fraca) E- e } \\
\text { P-caderina }\end{array}$ & $\begin{array}{l}\text { Camada superficial: } \\
\text { integrina beta-1 e beta-4, E- } \\
\text { caderina, CK } 10 \text { e INV } \\
\text { Camada intermediária: } \\
\text { integrina beta-1 e beta-4, E- } \\
\text { caderina e CK } 10 \\
\text { Camada basal: integrina } \\
\text { beta-4 (marcação } \\
\text { polarizada), E- e P-caderina, } \\
\text { CK } 14\end{array}$ & $\begin{array}{l}\text { Camada espinhosa: } \\
\text { integrina beta-1 e beta-4, E- } \\
\text { e P-caderina e CK10 } \\
\text { Camada basal: integrina } \\
\text { beta-1 e beta-4 (marcação } \\
\text { polarizada), E- e P-caderina e } \\
\text { CK } 14\end{array}$ \\
\hline
\end{tabular}


Figura 2: Expressão de integrinas e caderinas na pele fetal humana
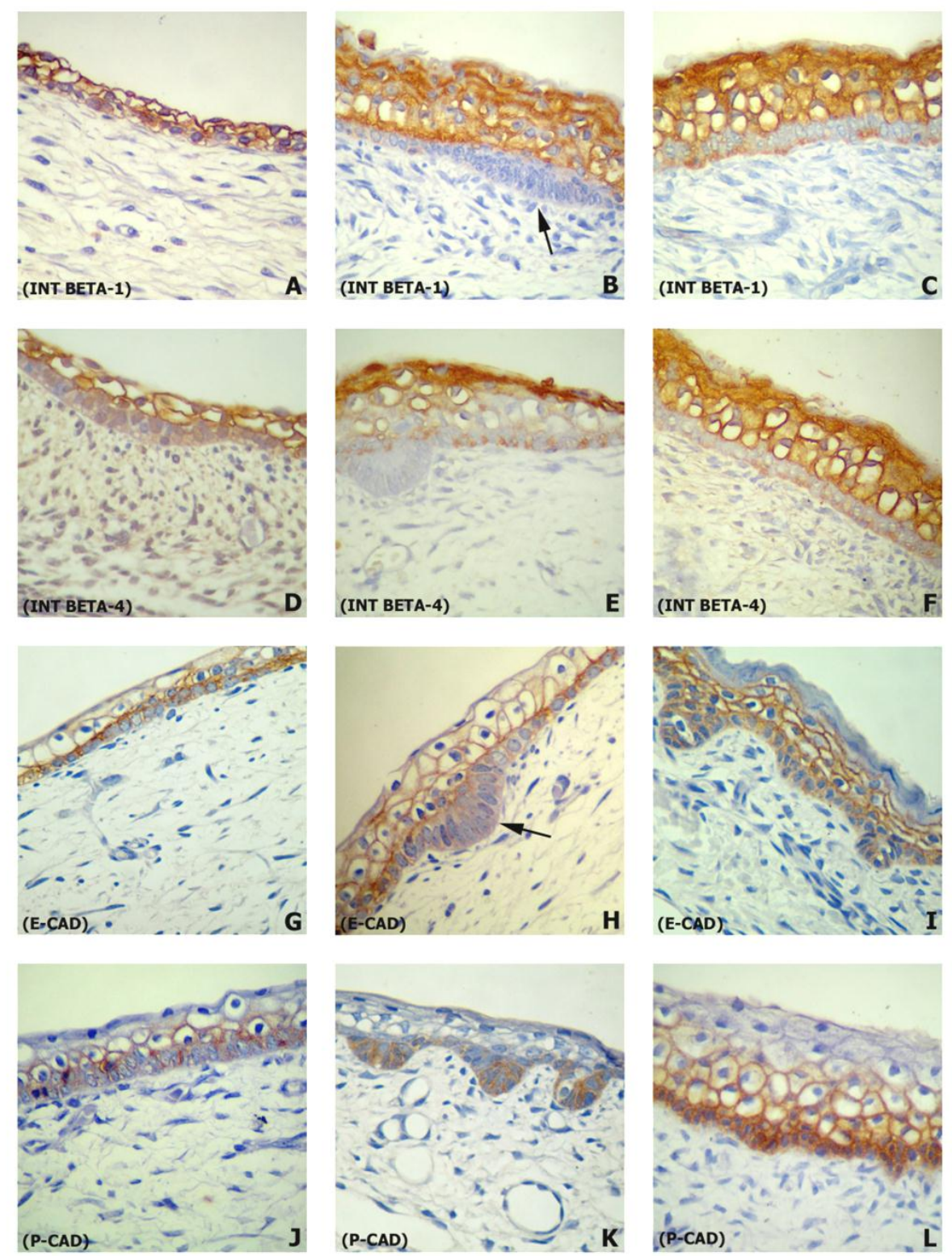
Legendas da Figura 2

A. Com 8 semanas a INT beta-1 é encontrada nas membranas dos queratinócitos na camada basal e periderme (aumento original X400).

B. Com 12 a 16 semanas, a INT beta-1 é observada em todas as camadas com exceção da basal. Como demonstrado pela a seta na imagem, onde há intensa atividade proliferativa a INT beta-1 é ausente (aumento original X400).

C. Com 24 semanas, a INT beta-1, está presente em todas as camadas supra basais e apresenta uma marcação polarizada na região onde há junção derme/epiderme (aumento original X400).

D. Com 8 semanas a INT beta-4 é expressa na periderme mas é fraca na camada basal (aumento original X400).

E. Com 12 a 16 semanas a INT beta-4 observada em todas as camadas. Na camada basal há a marcação polarizada (aumento original X400).

F. Com 24 semanas, apresenta a marcação semelhante a INT beta-1 e portanto está presente em todas as camadas supra basais e apresenta uma marcação polarizada na região onde há junção derme/epiderme (aumento original X400).

G. Com 8 semanas, a E-cad é positiva nas células presentes na camada basal (aumento original $\mathrm{X} 400)$.

H. Com 12 a 16 semanas, com o epitélio mais estratificado, a E-cad está nas células em todas as camadas e mais concentrada na camada basal. Onde há o processo de proliferação celular a expressão da E-cad é fraca (aumento original X400).

I. Com 24 semanas, a E-cad está em todas as camadas da epiderme de modo bastante expressivo (aumento original X400). 
J. Com 8 semanas, a P-cad está na camada basal (aumento original X400).

K. Com 12 a 16 semanas, é possível observar a P-cad mais concentrada nos locais onde há células em proliferação celular (aumento original X400).

L. Com 24 semanas, a P-cad está nos espaços intercelulares nas Camadas basais e intermediárias (aumento original X400). 
Figura 3: Expressão das citoqueratinas 10 e 14 e involucrina na pele fetal humana
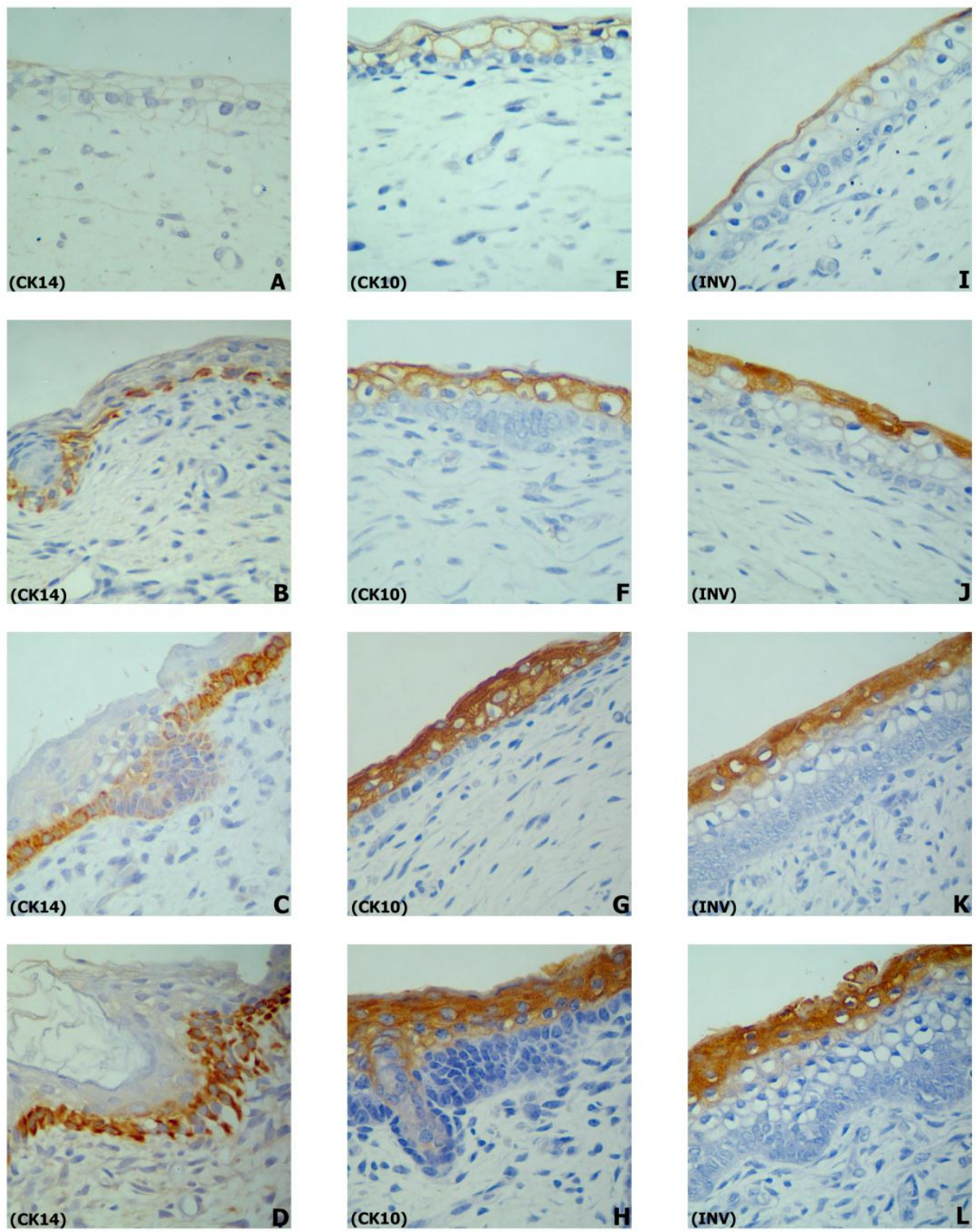
Legendas da Figura 3:

A. Com 8 semanas a expressão da CK 14 foi fraca e em alguns caso foi negativa na periderme (aumento original $\mathrm{X} 400$ ).

B. A partir da 9,5 semanas de gestação a CK 14 foi observada na camada basal (aumento original X400).

C. Imagem com 14 semanas há uma intensa expressão da CK 14 na camada basal, porém em regiões onde havia o processo de proliferação celular, a marcação da CK 14 foi fraca (aumento original X400).

D. Com 24 semanas (aumento original $\mathrm{X} 400$ ).

E. Com 8 semanas, a CK 10, embora quase inexpressiva, é encontrada na periderme (aumento original X400).

F. Com 14 semanas, na periderme com intensa atividade celular, é possível encontrar a CK 10 mais presente nas membranas dos queratinócitos (aumento original X400).

G. 18 semanas na camada intermediária da epiderme a CK 10 é bem mais presente (aumento original X400).

H. 24 semanas na camada espinhosa e granulosa da epiderme (aumento original $\mathrm{X} 400)$.

I. Com 8 semanas a INV foi observada como uma fina camada superficial que recobria os queratinócitos na periderme (aumento original X400).

J. 12 semanas, a expressão da INV aumenta conforme a estratificação da epiderme (aumento original X400).

K. 18 semanas, mantém a expressão mais superficial e aumentado conforme o grau de desenvolvimento da epiderme (aumento original X400). 
L. Com 24 semanas, em uma epiderme mais estratificada e com uma conformação mais próxima a um tecido mais maturo e característico, a marcação da INV é bem intensa (aumento original X400). 
Figura 4: Expressão de integrinas e caderinas na pele humana adulta
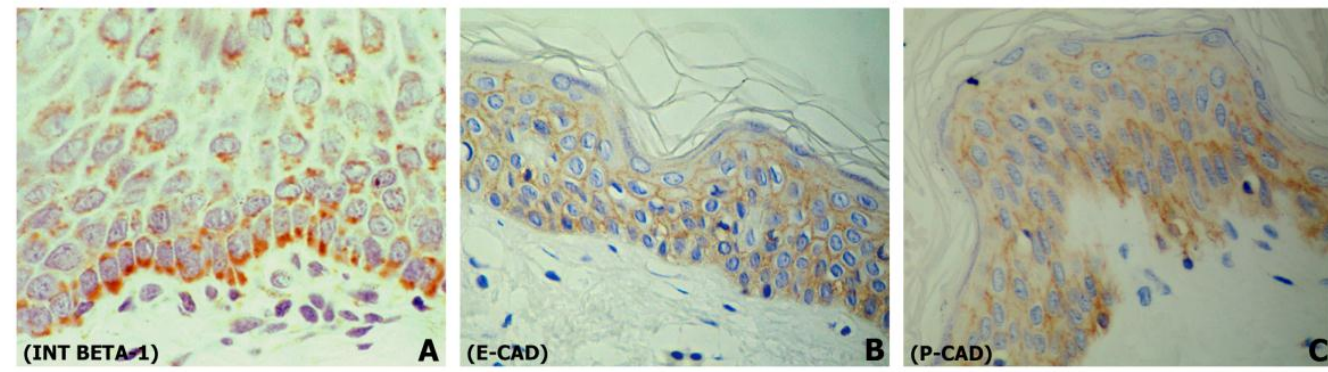

Figura A: A expressão polarizada da Integrina beta-1 é observada na membrana do pólo apical e basal nos queratinócitos presentes na camada basal e supra basal. Na integrina beta-4 houve o mesmo padrão e comportamento da expressão citada.

Figura B: A E-caderina foi positiva na membrana dos queratinócitos na camada basal, supra basal, e intermediárias da epiderme.

Figura C: A P-caderina foi encontrada principalmente nos queratinócitos basais em determinadas áreas de forma mais concentrada e em alguns supra-basais. 


\section{DISCUSSÃO}

Os resultados da análise morfológica dos fragmentos de pele nos seus vários estágios de desenvolvimento, provenientes de fetos entre 4 e 24 semanas de vida intrauterina mostraram que o desenvolvimento tanto da pele ocorre em tempos diferentes nos diferentes locais anatômicos e que em uma mesma localização podem-se observar estruturas em diferentes estágios da diferenciação.

No que tange os aspectos morfológicos, verificou-se que nos espécimes estudados o revestimento epitelial - periderme e epiderme sempre estiveram presentes no material analisado, sendo nos estágios mais iniciais observada a perideme - camada de revestimento epitelial composta de 2 ou 3 camadas de queratinócitos e, em fases mais tardias a epiderme em fase mais similar ao que se é descrito no adulto. Essas observações corroboram as de Murphy, 1997 em sua clássica descrição sobre o desenvolvimento das estruturas cutâneas.

A partir das fases mais iniciais, o desenvolvimento da pele ocorre de forma progressiva e coordenada com a função de preparar e proteger o embrião/feto para o momento do nascimento e os estímulos do meio ambiente. A compreensão das etapas em que essa maturação ocorre é importante para um entendimento da estrutura normal da pele e suas funções também no adulto.

Em uma análise paralela, foi observado que a expressão de moléculas de adesão de citoqueratinas e da involucrina durante o desenvolvimento cutâneo é dinâmica e muda de acordo com a progressão da maturação cutânea como 
demonstrado por autores sobre o estudo da pele e outros órgãos (Dale, 1985; Banks-Schelegel, 1982; Kasper, 1989).

Desde as fases mais iniciais do desenvolvimento notou-se a expressão de citoqueratinas nas células epiteliais do revestimento. Essas citoqueratinas, parte do citoesqueleto das células epiteliais só assumiram um padrão de expressão parecido com o da pele madura nas fases mais tardias do desenvolvimento incluídas em nosso estudo. Nas fases mais iniciais observou-se a expressão da CK14 praticamente em todas as camadas do epitélio, e, mais tardiamente, as outras citoqueratinas características da pele foram então detectadas nas camadas diversas da epidermeCK14 nas camadas basal e parabasal e CK 10 nas camadas mais superficiais do epitélio. Essas observações são apoiadas por outros estudos que relatam o desenvolvimento cutâneo e descrevem a maturação e queratinização ao redor da 23ạ semana de VIU, na área do estrato intermediário, com a presença de grânulos querato-hialinos (Murphy, 1997).

Nos locais onde havia a alta atividade proliferativa das células basais, processo muito comum durante o período fetal e na formação de anexos cutâneos, notou-se a ausência das citoqueratinas. Esta observação concorda com os estudos do desenvolvimento da epiderme humana envolvendo a microscopia eletrônica, os quais possuem as células basais pouco constituídas por estruturas de adesão e filamentos intermediários, o que confere vantagens migratórias para que as células epiteliais se movimentem em direção ao mesênquima para formar os anexos cutâneos (Dale et al, 1985). 
Com relação às moléculas de adesão, informações importantes foram produzidas em nosso trabalho: nas fases mais iniciais do desenvolvimento, quando a pele e os seus anexos ainda são bastante imaturos e não apresentam os marcadores clássicos de sua maturação, a presença de integrinas, que na pele adulta classicamente se apresentam nas camadas mais inferiores do epitélio, exibiam expressão em todas as camadas do revestimento epitelial e pouca expressão na camada basal. Esse padrão se alterou à medida da maturação epitelial e então podiam-se observar os padrões de expressão mais clássicos que consistem da presença da integrina beta 1 e beta 4 nos queratinócitos basais. Em contrapartida, a P-caderina apresentava, já nos espécimes de pele mais imaturos, expressão nos queratinocitos da camada basal, num mecanismo aparentemente compensatório ao das integrinas, proporcionando adesão entre o epitélio e o tecido conjuntivo. Com a progressão do desenvolvimento essa expressão diminuía até o quase completo desaparecimento nas fases mais tardias do desenvolvimento da pele. A E-caderina estava presente nos espaços intercelulares de praticamente todas as camadas epiteliais em todas as fases do desenvolvimento.

De acordo com Koizumi et al as caderinas, especialmente a E-caderina, são importantes na formação das camadas epiteliais, as quais se iniciam quando o contato incial célula-célula ocorre pela associação de complexos E-caderina/ Betacatenina. A evidente expressão de caderinas, principalmente da E-caderina durante o desenvolvimento demonstra mais uma vez a presença estrutural dessas moléculas nos desmosomos, principal estrutura adesiva da pele, que formam pontes adesivas 
entre os queratinócitos, com a função de adesão e resistência ao estresse mecânico que a pele é submetida durante a vida.

Nas últimas décadas essas estruturas têm sido alvo de estudos devido à importância sua importância em diversas doenças da pele. Nesses estudos, a estrutura molecular dos desmosomos vem sendo desvendada e as caderinas aparecem como moléculas-chave no processo da adesividade dos queratinócitos na inter-relação entre células vizinhas por meio do citoesqueleto (Amagai et al, 1991; Amagai, 1995; Buxton \& Magee, 1992). Como pudemos evidenciar em nosso trabalho, essa função já é primordial desde a VIU e a perda ou alteração de função das moléculas que compõem os desmosomos podem produzir doenças graves como o pênfigo vulgar e o pênfigo foliáceo (fogo selvagem).

Durante a embriogênese as integrinas parecem também estar envolvidas com processos adesão e organização tecidual, bem como no posicionamento dos órgãos e tecidos em desenvolvimento, uma vez que o formato final de um órgão, bem como sua posição, é conseqüência de propriedades genéticas intrínsecas e interações com os tecidos adjacentes. Em modelo de estudo utilizando glândulas salivares de Drosófilas devido à sua simplicidade estrutural, Bradley et al (2003) mostraram que subunidades de integrinas são responsáveis pela adesão e reconhecimento de certas áreas do mesoderma como substrato para seu desenvolvimento além de estarem relacionadas à mobilidade celular por meio da ativação de eventos sinalizadores. Esse potencial ativador também já foi descrito e explorado em trabalhos anteriores que atribuíram às integrinas a capacidade de 
ativação da expressão genética por meio de sinalização intracelular (MartinBermudo \& Brown, 1999).

Sabemos hoje, que mais do que a função adesiva, as integrinas participam ativamente de processos que incluem a diferenciação e a sinalização celular. Relatos também indicam que a integrina $\beta 1$ está relacionada a células-tronco e que essa proteína seria marcadora do nicho dessas células, impedindo que a falta de uma adesão ineficiente direcionasse tais células para processos de diferenciação (Watt et al, 1994). Na pele, provavelmente essa integrina tem a função inicial de proporcionar adesão fraca entre os queratinócitos no sentido de organizar esse tecido e ainda permitir que células proliferem e migrem para o mesênquima para a formação dos anexos cutâneos. Mais tardiamente, o padrão de adesão muda para que a pele possa, por meio da firme adesão dos queratinócitos que a compõe, executar sua principal função fisiológica que é a proteção.

Em 2000 e 2001 Faraldo et al publicaram trabalhos enfatizando a importância da integrina beta 1 no desenvolvimento e função da glândula mamária, relacionando a molécula a vias importantes de sinalização intracelular e com o controle da proliferação, apoptose, diferenciação e manutenção da polaridade baso-apical no epitélio mamário. Na mesma linha de estudos, Fässler et al em 1996 apontaram para a importância da integrina $\beta 1$ na diferenciação e função de cardiomiócitos, mostrando especialmente seu papel na organização da arquitetura sarcomérica dessas células em modelos in vivo e in vitro. Coraux et al estudaram a expressão da integrina $\beta 1$ no desenvolvimento da traquéia mostrando sua fundamental participação na morfo-diferenciação dessa estrutura. Esses autores 
relataram que a subunidade $\beta 1$ parece ainda estar relacionada aos processos de migração celular e formação tubular das vias aéreas.

Os nossos resultados, apresentados neste trabalho e em publicação em periódico científico de circulação internacional (Lourenço et al, 2007) delineiam evidências da importante participação das integrinas, principalmente da subunidade $\beta 1$ no desenvolvimento (morfo e citodiferenciação) e provavelmente na função da pele. A expressão da integrina beta-1 foi anteriormente descrita por Hertle et al com 8 semanas e integrinas beta-1 e -4 por Hentula et al no mesmo momento.

Corroborando nossas idéias, Schackleton et al (2006), publicaram na revista Nature resultados de pesquisa que mostra a participação da integrina $\beta 1$ na identificação de sub-populações de células progenitoras na glândula mamária, com o potencial de reconstituir, uma vez isoladas novas estruturas glandulares (árvore glandular completa). Nesses experimentos os autores especulam sobre o papel das subunidades de integrinas $\beta 1$ e $\alpha 6$ na interação com o estroma mamário.

Outros autores mostram que heterodímeros da integrina $\beta 1$ são expressos em vários processos de desenvolvimento, incluindo a condrogênese, fusão de mioblastos, morfogênese da pele e anexos (Brakebusch et al, 2000; Graus-Porta et al, 2001; Aszodi et al, 2003). Na glândula mamária, a participação das integrinas tem sido mais explorada por diversos e excelentes grupos de pesquisadores que estudam o tema em modelos in vitro. Sabe-se que nessas glândulas a adesão entre células e matriz regula a estrutura e função e que essa interação ocorre 
principalmente por meio das integrinas da família $\beta 1$ (Barcellos-Hoff et al, 1989; Streuli et al, 1991; Pullan et al, 1996; Prince et al, 2002).

O grupo do renomado pesquisador Streuli, demonstrou o importante papel da integrina $\beta 1$ na diferenciação e expressão de genéticas tecidual específica, gerando importantes evidências da participação de efeitos dependentes de integrina na expressão genética relacionada à diferenciação em alguns sistemas in vivo (Naylor et al, 2005). O grupo mostra que a integrina $\beta 1$ é molécula crítica para a morfogênese alveolar e para a manutenção das funções da glândula mamária diferenciada, estando envolvida em interações complexas com citocinas e rede de sinalização molecular. Nossos resultados, embora tenham explorado aspectos mais simples da diferenciação da pele também sugerem uma participação crucial dessa molécula nos diversos processos de formação e maturação dessas estruturas e, no futuro, pretendemos explorar os aspectos mais complexos do envolvimento da integrina $\beta 1$ na manutenção da estrutura e função das estruturas cutânea, assunto que certamente tem grande potencial de pesquisa.

Outros autores identificam as integrinas como importantes reguladores do crescimento e diferenciação de outros tipos de epitélio, devido às suas funções de promover ancoragem, proliferação, sobrevivência, migração e indução de enzimas que degradam a matriz extracelular quando necessário (Taddei et al, 2003). Esses eventos são provavelmente dependentes das não só da subunidade de integrina $\beta 1$, mas também da $\beta 4$. Esse tipo de situação também deve se reproduzir no epitélio cutâneo e os nossos resultados, de certa forma, retratam um panorama de 
importante participação dessas moléculas durante o desenvolvimento. Ainda, a importância dos níveis de expressão da integrina $\beta 4$ provavelmente se deve à necessidade da presença de hemidesmosomos e polaridade celular bem estabelecida para que a diferenciação terminal pele e anexos ocorra.

Todos os nossos resultados e os relatos de outros autores apóiam a hipótese de que as moléculas de adesão e em particular as integrinas são imprescindíveis nos estágios iniciais da organogênese (em funções de coordenação e integração de eventos que afetam a proliferação e morfogênese), e em fase adulta, na manutenção da integridade morfológica e funcional dos tecidos. Alguns desses aspectos já têm também sido descritos no desenvolvimento das glândulas salivares de ratos e Hamsters (Menko et al, 2001; Fernandes et al, 1999).

A participação das integrinas no desenvolvimento é, enfim, assunto em voga na literatura científica, com autores tentando compreender sua participação na formação dos mais diversos tecidos e relacionar esses aspectos aos dos marcadores característicos de cada célula.

Essas hipóteses só poderão ser esclarecidas com estudos funcionais envolvendo técnicas de cultivo celular, animais experimentais e técnicas de ponta na área da biologia molecular de sinalização intracelular. 


\section{CONCLUSÃO}

As moléculas de adesão apresentam tipos de expressão variável durante o desenvolvimento, sugerindo um importante papel durante o processo de estratificação:

1. As caderinas $E$ e $P$ estão presentes nas diversas camadas epiteliais e são parte integrante da estrutura adesiva da pele durante o desenvolvimento do epitélio cutâneo humano;

2. As integrinas são indispensáveis nas fases iniciais da organogênese e, nas fases mais desenvolvidas do desenvolvimento cutâneo, na integridade morfológica e função de manutenção tecidual. A observação de sua expressão polarizada na membrana basal é uma informação importante no que se refere na existência de uma "força de junção" para manter o epitélio fortemente aderido à sua derme subjacente;

3. A expressão das caderinas e integrinas é temporal e espacialmente regulada e está relacionada com a presença de marcadores citoesqueléticos (citoqueratinas) e do envelope celular (involucrina) durante o desenvolvimento do epitélio cutâneo humano; a ausência das caderinas e 
integrinas e a fraca expressão de filamentos intermediários nos locais de proliferação celular é uma indicação da mobilização dinâmica dessas proteínas com o processo de migração celular que ocorre no desenvolvimento epitelial e formação dos anexos cutâneos. 


\section{REFERÊNCIAS}

Amagai M, Klaus KV, Sanley J R. Autoantibodies against a novel epithelial cadherin in pemphigus vulgaris: a disease of cell adhesion. Cell, 67:869, 1991.

Amagai M. Adhesion molecules I: Keratinocyte interactions: cadherins and pemphigus. Prog Dermatol, 104:146, 1995.

Andreoli T E. Cell adhesion molecules and human disease. Am J Med, 106: 466-476, 1999.

Aszodi A, Hunziker E B, Brakebusch C, Fassler R. Beta 1 integrins regulate chondrocyte rotation, G1 progression and cytokinesis. Genes Dev, 17:2465-2479, 2003.

Bagutti C, Hutter C, Chiquet-Ehrismann R, Fassler R, Watt F M. Dermal fibroblast-derived growth factors restore the ability of $\beta 1$ integrin-deficient embrional stem cells to differentiate into keratinocytes. Dev Biol, 231, 321-333, 2001.

Banks-Schlegel S P, Keratin alterations during embryonic epidermal differentiation: a presage of adult epidermal maturation. J Cell Biol 1982; 93: 551. 
Belda Jr W, Chiacchio N, Criado P R. Tratado de Dermatologia. Ed Atheneu, 1:3-14, 2010.

Beauvais-Jouneau A, Thierry JP. Multiple roles for integrins during development.

Biol Cell, 89:5-11, 1997.

Brakebusch C, Grose R, Quondamatteo F, Ramirez A, Jorcano JL, Pirro A, Svensson M, Herken R, Sasaki T, Timpl R, Werner S, Fassler R. Skin and hair follicle integrity is crucially dependent on beta 1 integrin expression on keratinocytes. Embo J; 19 (15): 990-4003, 2000

Carlson BM. Embriologia humana e biologia do desenvolvimento. Guanabara e Koogan, 1994.

Carlston B. Embriologia Humana e Biologia do desenvolvimento. Guanabara \& Koogan, 1994.

Catala M. Embriologia: desenvolvimento humano inicial. Guanabara e Koogan, 1923, 2003.

Furukawa F, Fujii K, Horiguchi Y, et al. Roles of E- and P-cadherin in the human skin. Microsc Res Tech 1997; 38: 343. 
Kierszenbaum A L. Histologia e Biologia Celular: uma introdução à Patologia. Elsevier, 2ª̣ edição, 1: 3,7,22,33,34,35,36, 2007.

Moll R, Moll I, wiest W. Changes in the patterns of cytokeratins polypeptides in epidermis and hair follicles during skin development in human fetuses. Differentiation 1983; 23:170.

Persaud TVN, Moore K L. Embriologia Básica. Elsevier, 7ạ edição, 6: 52-63, 2008.

Chénard M, Basque JR, Chailler P, Tremblay E, Beaulieu JF, Ménard D. Expression of integrin subunits correlates with differentiation of epithelial cell lineages in developing human gastric mucosa. Anat Embryol, 202: 223-233, 2000.

Cooper GM. A célula: uma abordagem molecular. Artmed, 2eedição, 464-465, 2002.

Coraux C, Zahm JM, Puchelle E, Gaillard D. $\beta 1$ integrins are involved in migration of human fetal tracheal epithelial cells and tubular morphogenesis. AJP- Lung Cell and Molec Physiol, 279: L224-L234, 2000.

Cozzani E, Cacciapuoti M, Parodi A. Adhesion molecules in keratinocyte. Clin Dermatol, 19: 544-550, 2001. 
Dale BA, Holbrook KA, Kimball JR, Hoff M, Sun T. Expression of epidermal keratins and filaggrin during human fetal skin development. J Cell Biol 1985; 101: 1257.

Darribère T, Skalski M, Cousin H, Gaultier A, Montmory C, Alfandary D. Integrins: Regulators of embryogenesis. Biol Cell, 92, 5-25, 2000.

De Arcangelis A, Georges Labouesse E. Integrin and ECM functions. Roles in vertebrate development. TIG, 16(9): 389-395, 2000.

Drake $\mathrm{CJ}$, Cheresh DA, Little CD. An antagonist of integrin alpha v beta 3 prevents maturation of blood vessels during embryonic neovascularization. J Cell Sci, 108: 26552661, 1995.

Dufour S, Duband JL, Humphies MJ, Obara M, Yamada KM, Thierry JP. Attachment, spreading and locomotion of avian neural crest are mediated by multiple adhesion sites on fibrinectin molecules. EMBO J, 7: 2661-2671, 1998.

Faraldo MF, Deugnier MA, Lukashev M, Thierry JP, Glukhova MA. Perturbation of $\beta 1$ integrin function alters the development of murine mammary gland. EMBO J, 17: 21392147, 1998. 
Fernandes RP, Cotanche DA, Lennon-Hopkins K, Erkan F, Menko AS, Kukuruzinska MA.

Differential expression of proliferative, cytoskeletal, and adhesive proteins during postnatal development of the hamster submandibular gland. Histochem Cell Biol; 111(2): 153$62,1999$.

Furukawa F, Fujii K, Horiguchi t, et al. Roles of E- and P- Cadherin in the human skin. Microsc res tech 1997; 38: 343.

Garcia SML, Fernadez CG. Embriologia. Artmed, 2o edição, 349, 2003.

Gartner LP, Hiatt JL. Tratado de histologia (Cell Biology and Histology). Guanabara e koogan, 1999.

Gartner LP, Hiatt JL. Atlas colorido de histologia. Guanabara e Koogan, 3o edição, 25-29, 2000.

Gartner LP, Hiatt JL. Tratado de histologia em cores. Guanabara e Koogan, 77-82, 1997.

Gartner LP, Hiatt JL. Tratado de histologia em cores. Guanabara e Koogan, 2음 edição, 2003. 
Giancotti FG, Ruoslahti E. Integrin signaling. Science, 285: 1028-1032, 1999.

Gitirana LB. Histologia: conceitos básicos dos tecidos. Atheneu, 1:15, 2004.

Gumbiner MB. Cell adhesion: the molecular basis of tissue architecture and morphogenesis. Cel, 84: 345-357, 1996.

Graus-Porta D, Blaess S, Senften M, Littlewood-Evans A, Damsky C, Huang Z, Orban P, Klein R, Schittny JC, Muller U. Beta1-class integrins regulate the development of laminae and folia in the cerebral and cerebellar cortex. Neuron; 31(3): 367-79,2001.

Hammes HP, Brownlee M, Jonczyck A, Sutter A, Preissner KT. Subcutaneous injection of a cyclic peptide antagonist of vitronectin receptor-type integrins inhibits retinal neovascularization. Nat Med, 2: 529-533, 1996.

Heino J. The collagen receptor integrins have distinct ligand recognition and signaling funtions. Matrix Biol, 19: 319-323, 2000.

Hemler ME. Integrin associated proteins. Curr Opin Cell Biol, 10: 578-585, 1998. 
Hentula M, Peltonen S. expression profiles of cell-cell and cell-matrix junction proteins in developing human epidermis. Arch dermatol res 2001; 2001; 293: 259.

Hertle M D, Adams j C, Watt F M. integrin expression during human epidermal development in vivo and in vitro. Development 1991; 112: 192.

Hotchin NA, Gandarillas A, Watt FM. Regulation of cell surface $\beta 1$ integrin levels during keratinocyte terminal differentiation. J Cell Biol, 128(6): 1209-1219, 1995.

Hynes RO. Cell adhesion: old and new questions. Trends Cell Biol, 9(12): M33-M37, 1999.

Hynes RO. Integrins: versatility, modulation and signaling in cell adhesion. Cell, 68: 11-25, 1992.

Junqueira LC, Carneiro J. Biologia Celular e Molecular.Guanabara e Koogan, 7음 edição, 122-123, 2000.

Junqueira LC, Carneiro J. Histologia básica. Guanabara e Koogan, 8o edição, 1995.

Junqueira LC, Carneiro J. Histologia básica. Guanabara e Koogan, 10 edição, 2004. 
Kerr JB. Atlas de histologia funcional. Artes médicas LTDA,145-149, 2000.

Kasper M, Stosick P. Immunohistochemical investigation of diferent cytokeratins and viment in the human epididymis from fetal period up to adulthood. Cell tissue res 1989; 257: 661

Lourenço SV, Kamibeppu L, Fernandes D, Sotto MN, Nico MMS. Relationship of adhesion molecules expression. With epithelial differentiation markers during fetal skin development. Journal of Cutaneous Pathology, 731-737, 2007.

Marchisio PC, Trusolino L, de Luca M. Topography and biological role of integrins in human skin. Microsc Res Tech, 38: 353-360, 1997.

Martin-Bermudo MD, Brown NH. The localized assembly of extracellular matrix integrin ligands requires cell-cell contact. J Cell Sci; 21: 3715-23, 2000.

Menko AS, Kreidberg JA, Ryan TT, Van Bockstaele E, Kukuruzinska MA. Loss of alpha3beta1 integrin function results in an altered differentiation program in the mouse submandibular gland. Dev Dyn; 220: 337-49, 2001. 
Moore KL, Persaud TVN. Embriologia básica. Guanabara e Koogan, 5 edição, 2000.

Moore KL, Persaud TVN, Shiota K. Atlas colorido de Embriologia clínica. Guanabara e Koogan, 2o edição, 50-59, 2008.

Naylor MJ, Li N, Cheung J, Lowe ET, Lambert E, Marlow R, Wang P, Schatzmann F, Wintermantel T, Schuetz G, Clarke AR, Mueller U, Hynes NE, Streuli CH. Ablation of beta1 integrin in mammary epithelium reveals a key role for integrin in glandular morphogenesis and differentiation. J Cell Biol; 171 (4): 717-28, 2005.

Petit V, Thierry JP. Focal adhesions: structure and dynamics. Bio Cell, 92: 477-494, 2000.

Pignatelli M, El-Bahrawy MA. E-Cadherin and Catenins: Molecules With Versatiles Roles in Normal and Neoplasic Epithelial Cell Biology. Microscopy Reserch and Techique, 43: 224-232, 1998.

Pullan S, Wilson J, Metcalfe A, Edwards GM, Goberdhan N, Tilly J, Hickman JA, Dive C, Streuli $\mathrm{CH}$. Requirement of basement membrane for the suppression of programmed cell death in mammary epithelium. J cell Sci; 109: 631-42, 1996. 
Sadler, T W. Embriologia médica (Embriology development). Guanabara e Koogan, $7^{\circ}$ edição: 229-230, 1997 (tradução).

Sastry SK, Lakonishok M, Thomas DA, Muschler J, Horwitz AF. Integrin alpha subunit ratios, cytoplasmic domains and growth factor synergy regulate muscle proliferation and differentiation. J Cell Biol, 133: 169-184, 1996.

Schoenwolf G C, Bleyl S B, Brawer P R, West P H F. Larsen: Embriologia Humana. Elsevier, 4aㅡ edição, 2009.

Stevens A, Lowe J. Histologia Humana (Human histology). Manole, 2ำedição, 18:359-361, 2001.

Takeichi M. Cadherin cell adhesion receptors as a morphogenetic regulator. Science, 251: 1451-1455, 1991.

Takeichi M. Cadherin: A molecular family important in selective cell-cell adhesion. Ann Rev Biochem, 59: 237-252, 1990. 
Taddei I; Faraldo MM; Teuliere J; Deugnier MA; Thiery JP; Glukhova MA Integrins in mammary gland development and differentiation of mammary epithelium. J Mammary Gland Biol Neoplasia; 8(4): 383-94, 2003.

Vleminckx K; Kemler R. Cadherins and tissue formation: integratin adhesion and signaling. Biossay, 21: 211-220, 1999

Yagi T, Takeichi M. Cadherin superfamily gens: functions, genomic organization and neurologic diversity. Genes Dev, 14: 1169-1180, 2000.

Zhang SX. Atlas de Histologia (Na Atlas of Histology by Shu- Xin Zhang). Guanabara e Koogan, 1999. 
9 Apêndice 


\section{Relationship of adhesion molecules expression with epithelial differentiation markers during fetal skin development}

Background: Cadherins and integrins are important for maintenance of tissue integrity and in signal transduction during skin development. Distribution of these molecules in human skin development was investigated and associated with markers of differentiation, cytokeratins (CK) and involucrin (INV).

Methods: Using immunohistochemistry expression of E- and Pcadherins, integrins beta-1 and -4, CK10, CK14 and INV was assessed in skin fragments of 10 human fetuses (gestational weeks ranged from 4 to 24 , all weighing up to $500 \mathrm{~g}$ ).

Results: At initial phases of development, integrins beta- 1 and -4 and $\mathrm{E}$ - and $\mathrm{P}$-cadherins were present on epithelial cell membranes in all layers. CK14 and CK10 were expressed in all epithelial layers and INV weakly detected in the superficial layer. In more advanced stages, integrins were detected in all layers, but a marked polarized expression was seen in basal layer. E-cadherin was detected in all layers, but the cornified stratum and P-cadherin were observed in the lower layers.

CK14 was expressed in basal layer, CK10 in suprabasal stratum and INV was observed in cornified layer.

Conclusions: Cadherins and integrins are essential for skin development, being spatially and temporally regulated. Their expression is related with the expression of maturation markers of the epidermis.

Lourenço SV, Kamibeppu L, Fernandes JD, Sotto MN, Nico MMS. Relationship of adhesion molecules expression with epithelial differentiation markers during fetal skin development.

J Cutan Pathol 2008; 35: 731-737. (C) Blackwell Munksgaard 2007.

\section{Silvia Vanessa Lourenço ${ }^{1,2}$, Leonardo Kamibeppu², Juliana Dumêt Fernandes ${ }^{3}$, Mirian Nacagami Sotto ${ }^{3}$ and Marcello Menta S. Nico ${ }^{3}$}

${ }^{1}$ Department of General Pathology, Dental School, University of São Paulo, São Paulo, Brazil,

${ }^{2}$ Tropical Medicine Institute, University of São Paulo, São Paulo, Brazil, and

${ }^{3}$ Department of Dermatology, Medical School, University of São Paulo, Brazil

Silvia Vanessa Lourenço, Disciplina de Patologia Geral, Faculdade de Odontologia, Universidade de

São Paulo, Av Prof Lineu Prestes, 2227,

CEP: 05508-000 São Paulo, SP-Brazil

Tel: +55 1130617062

Fax: +55 1130617065

e-mail: sloducca@usp.br

Accepted for publication August 22, 2007
Differentiation of the skin is governed by reciprocal interactions between the epithelium and the mesenchyme. The epithelial placode induces the condensation of mesenchymal cells, and then the condensed mesenchyme instructs the epithelium to differentiate into region-specific cutaneous structures. The molecular mechanisms of such interactions are not completely clear. $^{1}$

In general terms, the epidermis begins as a single layer of ectodermal cells, which by 5 weeks of gestational age differentiate into two layers - basal layer and periderm. By 10 weeks the stratum intermedium develops and by 19 weeks there are several layers of intermediate cells. Keratinization is well developed by 23 weeks within the stratum intermedium with notable presence of small keratohyaline granules. At this time, most of the periderm cells have shed, and the keratinizing cells that remain beneath represent the newly formed stratum corneum. ${ }^{2}$

During these phases of skin development, epithelial cells undergo maturation phases, and this can be assessed analyzing the patterns of intermediate filaments expression as well as proteins of the 


\section{Lourenço et al.}

cornified envelope. ${ }^{3-5}$ Concomitantly, the epithelial cells forming the epidermis establish contacts that are important for maintaining tissue integrity and for the subsequent steps of epithelial maturation.

It is known that various classes of cell-cell adhesion molecules are differently expressed in the skin from early development to adulthood. Among those, $\mathrm{E}$ - and P-cadherins and integrins beta- 1 and beta- 4 are important not only for cell-cell adhesion and maintenance of tissue integrity but also for signal transduction and evolution of the developmental steps of skin histo and morphogenesis leading to an adult and mature tissue. ${ }^{6}$

The present study investigated the morphological distribution of $\mathrm{E}$ - and $\mathrm{P}$-cadherins and integrins beta- 1 and beta- 4 in human skin development and associated their expression with some markers of differentiation of the skin-cytokeratins $(\mathrm{CK})$ and involucrin (INV).

\section{Materials and methods}

Tissue preparation

Fragments of skin from post mortem human fetuses at 4th to 24th weeks of gestation were obtained from the University of São Paulo Medical School Hospital and in accordance with authorization of the Ethical Committee of this institution. The specimens were collected from different regions of fetal skin. Fully developed skin specimens were retrieved from the archives of the Laboratory of Dermatopathology of the same institution and were used as controls. All specimens were fixed in $10 \%$ buffered formalin for $24 \mathrm{~h}$ and embedded in paraffin. They were then histologically processed, serial-sectioned and stained with hematoxylin and eosin to check for their morphology. Those presenting good morphological structure were selected for the present immunohistochemical analysis.

\section{Immunohistochemistry}

Three-micrometer serial sections of the specimens were re-hydrated and incubated in $3 \%$ aqueous hydrogen peroxide for $30 \mathrm{~min}$ to quench endogenous peroxidase activity. Incubation with $1 \%$ bovine serum albumin and 5\% fetal calf serum in Tris- $\mathrm{HCl}$ $\mathrm{pH} 7.4$ for $60 \mathrm{~min}$ at room temperature was performed to suppress non-specific binding of subsequent reagents. The sections were then submitted to antigen retrieval procedures, followed by incubation overnight with the primary antibody. The primary antibodies' information such as clone, source and title as well as other protocol details are described in Table 1. The reaction followed with incubation with the indirect dextran polymer detec- tion system (En Vision; Dako Carpinteria, CA, USA). Staining was completed by incubation with 3'3-diaminobenzidine tetrachloride for $3 \mathrm{~min}$. The specimens were then lightly counterstained with Mayer's hematoxylin, dehydrated and mounted with glass cover slip and xylene based mountant.

Negative controls were achieved by substituting primary specific antibodies with non-immune serum, and internal positive controls were considered according to primary serum manufacturer's datasheet recommendation.

All immunohistochemical reactions were carried out in triplicate.

All slides were analyzed morphologically under conventional light microscope equipped with a digital camera for photographical documentation of the results (Table 2).

\section{Results}

In the very early phases of skin development (periderm) when epidermis was restricted to 2-3 cell layers (at around 8 and 9 weeks of gestational age), integrins beta- 1 and beta-4 were detected around the cell membrane of all epithelial layers (Fig. 1A and 1D). E-cadherin expression was also observed from the stage of periderm with epithelial cells being positive for this adhesion molecule in all layers (Fig. 1G). The patterns of P-cadherin expression were variable during the epidermis differentiation and maturation. In early phases of skin differentiation, P-cadherin was present in the lower layers of the epidermis, surrounding the cell membrane of the very immature keratinocytes (Fig. 1J).

In this phase, expression of CK14 and CK10 was weak, almost undetectable and only a very weak and thin layer positive for INV was observed (Fig. $3 \mathrm{~A}, \mathrm{E}, \mathrm{I}$, respectively).

In a further development stage (at around 1214 weeks of gestational age), when epidermis was composed by a well-stratified epithelium, integrins beta- 1 and beta- 4 were still detected in almost all epithelial layers (Fig. 1B,E). In this phase, basal layer and areas where nests of epithelial cell seemed to proliferate and bud into the underlying mesenchyme, cells were negative for both integrins subunits. The expression of E-cadherin became stronger in the basal and intermediate layers of the epidermis at this stage (Fig. 1H). P-cadherin was only expressed in the nests of epithelial proliferation that were observed to invade toward the underlying mesenchyme (Fig. 1K).

CK14 was now observed in the basal layer (Fig. 3B). Areas where nests of epithelial proliferation budded toward the mesenchyme were negative for CK14. CK10 was expressed in the suprabasal layers, and thin layer positive for INV was also seen in this phase (Fig. 3J and 3F). 
Adhesion molecules in human skin development

Table 1. Primary antibodies, clones, manufacturer, title and antigen retrieval

\begin{tabular}{|c|c|c|c|c|}
\hline Primary serum & Clone & Manufacturer & Title & Antigen retrieval \\
\hline E-cadherin & 36B5 & Novocastra & $1: 100$ & Citrate $\mathrm{pH} 6.0$ in microwave \\
\hline P-cadherin & $56 \mathrm{C} 1$ & Novocastra & $1: 100$ & Citrate pH 6.0 in microwave \\
\hline Integrin beta-1 & $6 \mathrm{~S} 6$ & Chemicon & $1: 100$ & Pepsin $0.5 \%$ at $37^{\circ} \mathrm{C}$ \\
\hline Integrin beta-4 & ASC-3 & Chemicon & $1: 100$ & Pepsin $0.5 \%$ at $37^{\circ} \mathrm{C}$ \\
\hline CK14 & CKB1 & Abcam & $1: 100$ & Citrate pH 6.0 in microwave \\
\hline CK10 & LHP1 & Abcam & $1: 100$ & Citrate $\mathrm{pH} 6.0$ in microwave \\
\hline Involucrin & SY5 & Novocastra & $1: 200$ & Citrate $\mathrm{pH} 6.0$ in microwave \\
\hline
\end{tabular}

When maturation of the epidermis was near its fully developed stage (at around 24 weeks of gestational age), integrin beta- 1 was seen in all epithelial layers, surrounding cell membranes and, in the basal cell layer, expression of this protein was observed in a polarized pattern, with its main presence at the basal pole of basal keratinocytes (Fig. 1C).

Integrin beta-4 expression presented a similar pattern observed for beta-1 integrin (Fig. 1F). In adult epidermis, these integrins were mainly expressed at the basal layer of keratinocytes, and only a weak expression of these adhesion molecules was seen in suprabasal layers of the stratified epithelium of skin (Fig. 2A). At this final maturation stage, the expression of E-cadherin became stronger in the basal and intermediate layers of the epidermis and by late differentiation phases, the outmost layer of the epidermis (keratinizing layer) was negative for this adhesion molecule (Fig. 1I). P-cadherin was present in the lower layers of the epidermis, and in adult mature skin, P-cadherin was almost absent (Fig. 1L).

In adult skin, the expression of integrin beta-1 was observed mainly in basal and suprabasal layers (Fig. 2A), and integrin beta-4 followed a similar pattern with marked presence in the basal pole and basolateral aspect of basal keratinocytes. E-cadherin was detected up to spinous layer, and P-cadherin was observed in focal areas surrounding the membrane of basal keratinocytes and in some keratinocytes of the upper layers (Fig. 2B,C, respectively).

The patterns of CKs and INV still remained unchanged, with CK14 being strongly positive in the basal layer, CK10 in the suprabasal layer and INV being expressed in the keratinizing outmost layers of the epithelium (Fig. 3C,G,K).
This pattern was held to adult mature skin (Fig. 3D,H,L).

\section{Discussion}

The present study analyzed the various patterns of adhesion molecules during the stages of human epidermis maturation. In all phases analyzed (specimens from fetuses ranging from 4 to 24 gestational weeks) - from periderm when skin is restricted to two or three cell layers, up to the more developed stages of skin maturation, we were able to identify adhesion molecules, which are essential for the development, growth and maturation of multicellular organisms and tissues.

In a parallel analysis, we observed that the patterns of $\mathrm{CKs}$ expression during skin development and maturation are dynamic and change according to the progression of skin maturation as shown by other authors for skin and other organs. ${ }^{3,7,8}$ We compared it with the presence and patterns of adhesion molecules expression for a better understanding of the integrated process of skin development. These results put together indicate that since the very early phases skin development functions progressively and coordinately to prepare and protect the fetus for birth and environmental stimuli. The comprehension of these maturation steps is important for understanding the normal structure of skin and its function in adults either in health or disease.

In human fetal skin, the patterns of cadherin expression are generally similar to those described by other authors for adult skin. Embryonic skin at 7-8 weeks of estimated gestational age consisting mainly of basal layer and periderm expressed E- and P-cadherin

Table 2. Presence of cadherins, integrins, cytokeratins and INV in different layers of developing epidermis at 8,12 and 24 weeks of gestational age

\begin{tabular}{|c|c|c|}
\hline 8 weeks & 12 weeks & $\begin{array}{l}24 \text { weeks } \\
\text { Cornified layer: INV }\end{array}$ \\
\hline $\begin{array}{l}\text { Peridermis: integrins beta- } 1 \text { and beta- } 4 \text {, } \\
\text { E-cadherin (weak), CK10 } \\
\text { Basal layer: integrins beta- } 1 \text { and beta- } 4 \text { (weak), } \\
\text { E- and P-cadherins }\end{array}$ & $\begin{array}{l}\text { Superficial layer: integrins beta- } 1 \text { and beta- } 4 \text {, } \\
\text { E-cadherin, CK10 and INV } \\
\text { Intermediate layer: integrins beta- } 1 \text { and beta- } 4 \text {, } \\
\text { E-cadherin and CK10 } \\
\text { Basal layer: integrin beta-4 (polarized pattern), } \\
\text { E- and P-cadherins, CK14 }\end{array}$ & $\begin{array}{l}\text { Granular layer: integrins beta- } 1 \text { and beta- } 4 \text {, } \\
\text { CK10 and INV } \\
\text { Spinous layer: integrins beta- } 1 \text { and beta- } 4 \text {, } \\
\text { E- and P-cadherins and CK10 } \\
\text { Basal layer: integrins beta-1, and beta- } 4 \\
\text { (polarized pattern), E- and P-cadherins, CK14 }\end{array}$ \\
\hline
\end{tabular}

CK, cytokeratin; INV, involucrin. 


\section{Lourenço et al.}
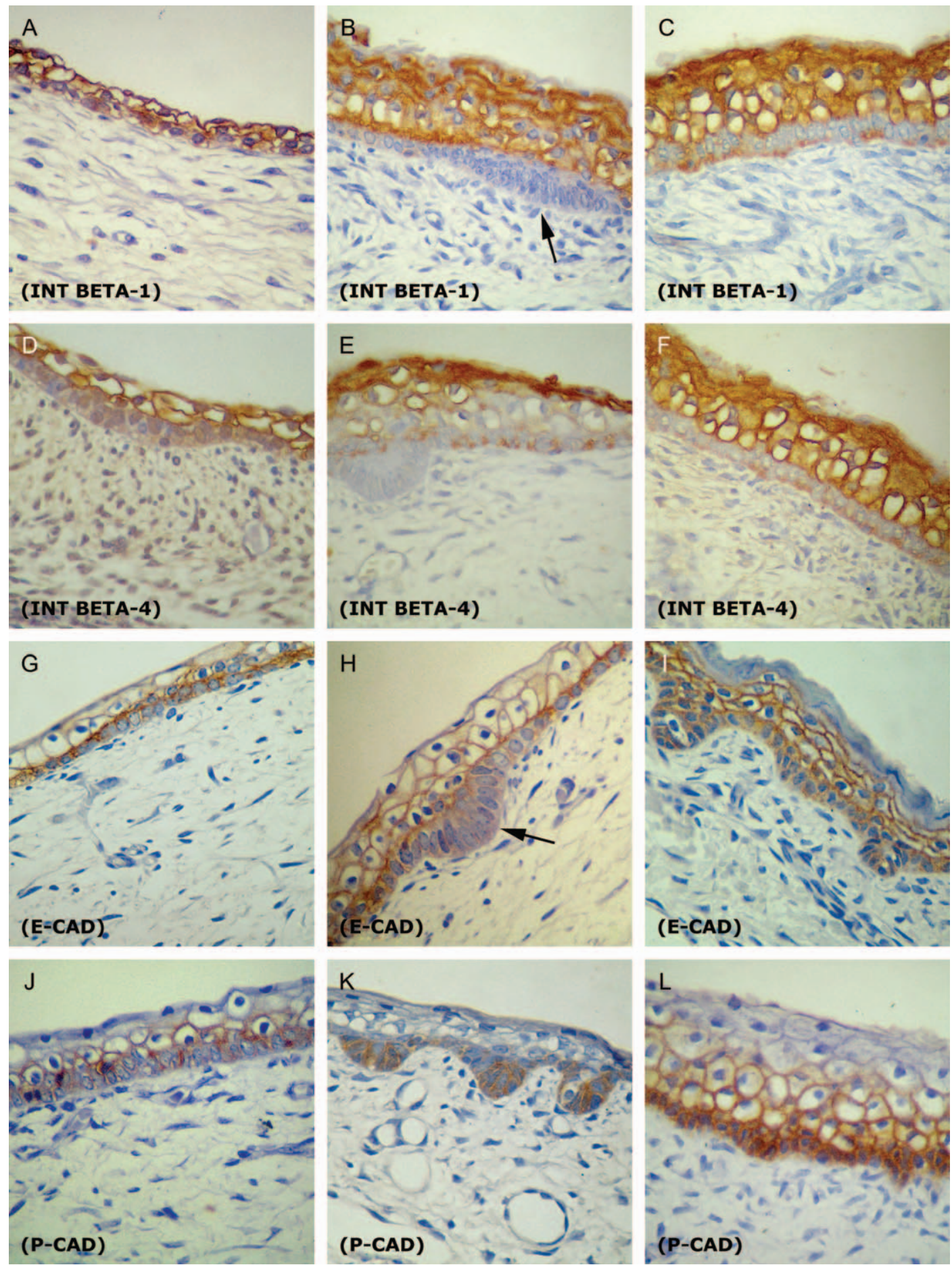

Fig. 1. Expression of adhesion molecules - integrins beta-1 and beta- 4 and E- and P-cadherins in human developing skin. At 8 weeks of gestational age, epidermis is formed by two or three layers of epithelial cells - basal layer and periderm. Integrin beta- 1 is present around the cell membrane of keratinocytes of all layers (A). Integrin beta-4 is observed mainly around the membranes of cell of periderm. Basal layer is weakly positive for this integrin (D). E- and P-cadherins are positive around the membranes of epithelial cells of the basal layer $(\mathrm{G}$ and $\mathrm{J}$, respectively) (original magnification $\times 400$ ). From 12th to 16 th weeks of gestational age, intermediate layer of keratinocytes can be observed. (B) Integrin beta-1 is positive in all cell layers, except for basal. Note the absence of beta-1 integrin in areas of basal cells proliferation (arrow). (E) Beta-4 integrin is positive in all layers and in the basal layer, a polarized pattern of positivity is observed. (H) E-cadherin is positive in all cell layers. In areas of basal cells proliferation, weak positivity is observed (arrow). (K) P-cadherin expression around keratinocytes membranes in areas of basal cell proliferation (original magnification $\times 400$ ). At 24 weeks of gestational age, skin is more matures and a cornified layer can be detected. $(\mathrm{C}$ and $\mathrm{F}$ ) Integrins beta- 1 and beta-4 still are positive in the intercellular contacts of intermediate layers of the epithelium. A marked polarized positivity in the area of dermal/epidermal junction is seen. (I and L) Immunoexpression of E- and P-cadherins is observed in the intercellular contacts of basal and intermediate layers (original magnification $\times 400$ ). 

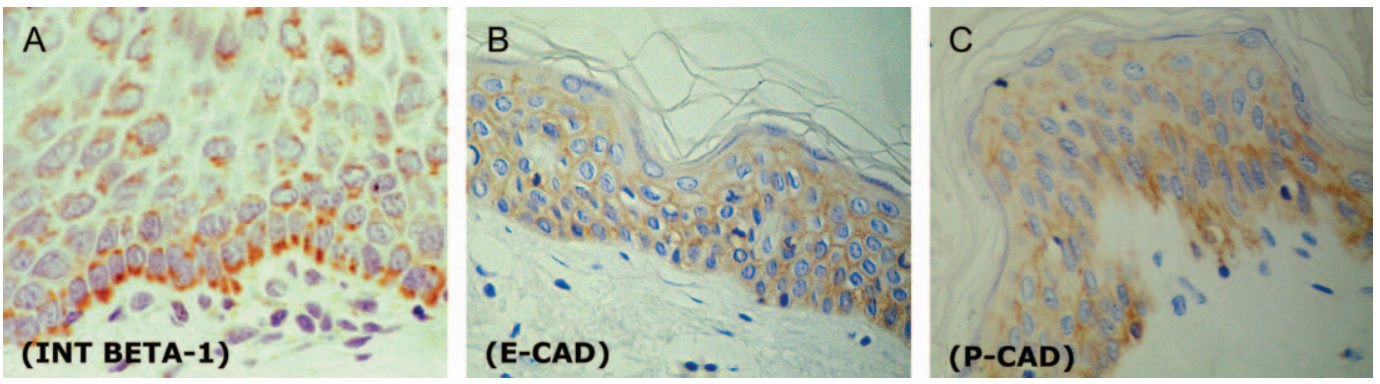

Fig. 2. Expression of adhesion molecules - integrins beta- 1 and $\mathrm{E}$ - and P-cadherins - in human adult skin (controls). (A) Integrin beta-1 is present as dots on the apical and basal poles of the membrane of basal keratinocytes. Keratinocytes positive for integrin beta- 1 are also observed in suprabasal layers. A similar pattern of expression was observed for integrin beta- 4 - figure not shown (original magnification $\times 400)$. (B) E-cadherin positivity around the membranes of keratinocytes of basal, suprabasal and intermediate layers of the epidermis (original magnification $\times 400$ ). (C) Expression of P-cadherin around the membrane of basal keratinocytes, mainly in focal areas. Some keratinocytes of upper layers are also positive for this protein (original magnification $\times 400$ ).

on the cell membranes of all layers, with a greater intensity in the basal layer. According to Koizumi et al. ${ }^{9}$ cadherins, especially E-cadherin are important in epithelial sheet formation, which starts when initial cell-cell contacts are formed by the association of the opposing E-cadherin/beta-catenin complexes. When further maturation was observed (at around 912 weeks of estimated gestational age, E-cadherin was still expressed in all layers of the fetal epidermis, and P-cadherin was concentrated in the proliferative compartment of epidermis. Later, when skin is further developed, closer to its adult pattern, E-cadherin was present up to keratinocyte layer, and P-cadherin is concentrated in the lower layers of the epidermis. These findings are in agreement with Furukawa et al. ${ }^{6}$ and highlight that cadherins are involved in vital processes such as embryogenesis, tissue and organ formation, being responsible for the maintenance of specific organ architecture. The patterns of $\mathrm{P}$-cadherin expression meet with the information published by Koizumi et al. ${ }^{9}$ who link the presence of this molecule with the proliferative compartment of re-epithelization of rat skin, and the phenomenon of delay or inhibition of terminal differentiation of keratinocytes.

Integrins beta- 1 and beta- 4 were detected in the various layers of the epidermis, from its very immature states. The presence of these integrins in early phases of skin development (periderm) was faintly detected around cell membranes of the few layers that compose the epithelium and later, their expression was stronger, but still seen on the membranes of the several layers of keratinocytes that compose the epidermis. Expression of beta-1 integrin was previously reported by Hertle et al. ${ }^{10}$ by 8 weeks of gestation and integrins beta- 1 and beta- 4 , by Hentula et al. ${ }^{2}$ at around the same time. The latter authors found the expression of integrins beta1 and beta- 4 not only at the basal aspect of basal cells, but also in the apicolateral membranes of these cells, suggesting that separation of cell membranes to the basal and apicolateral compartments does not occur before proper development of basement membrane zone. Our results agree with those and also propose that these molecules are important in the organization of early epidermis, as they are detected in the various keratinocytes layers during skin development.

As skin development proceeds, just before a marked stratification (at around 9 weeks of gestation), both integrins beta- 1 and beta- 4 appear to be more prominent in the basal aspect of basal cells (at dermal/ epidermal junction). However, they are still present around other areas of cell membrane. This pattern is consistent with the reported appearance of hemidesmosomes and increased anchoring fibrils. ${ }^{10-13}$

As stratification of epidermis occurs and an intermediate layer of keratinocytes is detected, integrins beta- 1 and beta- 4 were still observed surrounding cell membrane in the various layers of keratinocytes, but a marked and polarized pattern of expression was noted in the basal cells. However, in areas where proliferative activity is present, these integrins are absent. This finding is probably because of the high rate of proliferation of basal cells, which is accentuated in the fetal period and contributes to the formation of epidermis annexes. In these areas, expression of CKs was also negative. This is also consistent with electron microscopy studies of developing human epidermis, in which basal cells have been noted to contain fewer adhesion structures and intermediate filaments. ${ }^{3}$

Finally, in normal epidermis, integrins are confined to the basal and parabasal layers (data not shown). The presence of integrins in several layers of immature skin shows that these molecules might play important roles in the proliferation and maturation of epithelial cells of the cutaneous epithelium during development up to its fully mature state. This pattern is also seen in some pathological conditions characterized by hyperproliferation 


\section{Lourenço et al.}
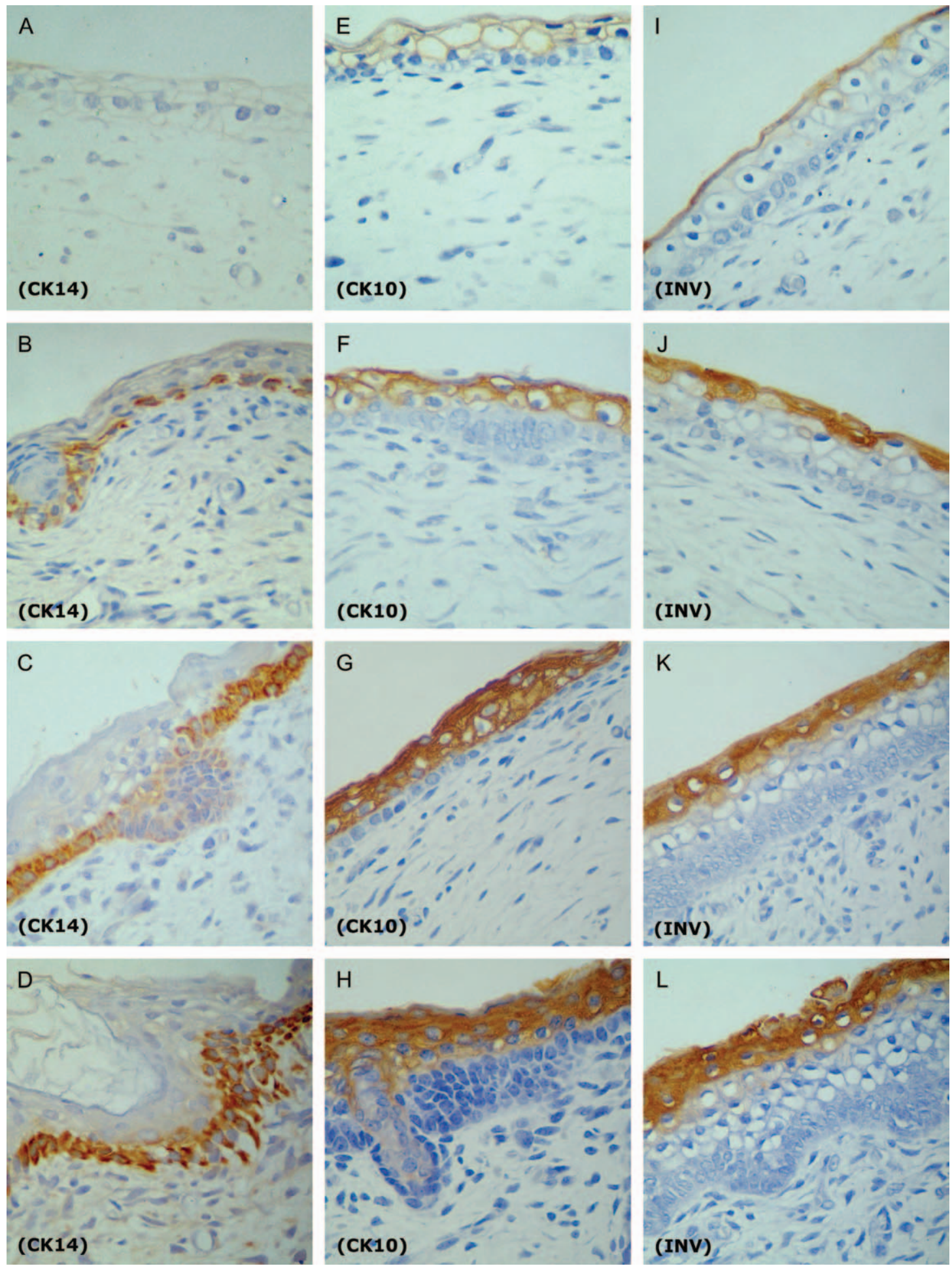

Fig. 3. Expression of cytokeratin and involucrin in developing human skin. At 8 weeks of gestational age, the presence of CK14 is very weak and, in most specimens, negative (A). From 9.5 weeks of gestational age up to the more developed phases of epidermis development, CK14 is strongly positive in the basal layer of the skin (Figures (B) - 9.5 weeks of gestational age; $(\mathrm{C})-14$ weeks of gestational age and (D) - 24 weeks of gestational age) (original magnification $\times 400$ ). At 8 and 5 weeks of gestational age, a faint expression of CK10 can be observed in the peridermis (E). In the more developed stages of skin development (up to 24 weeks of gestational age here represented in $(\mathrm{H})$, CK10 is present in the peridermis ( $\mathrm{F}-14$ weeks of gestational age), intermediate $(\mathrm{G}-18$ weeks of gestational age), spinous and granular layers (H - 24 weeks of gestational age) of the cutaneous epithelium (original magnification $\times 400$ ). Involucrin is observed as a very thin layer in periderm at around 10 weeks of gestational age (I) and increases its expression in the granular and cornified layers up to the more developed stages of skin development $(\mathrm{J}-12$ weeks of gestational age; $\mathrm{K}-18$ weeks of gestational age and $\mathrm{L}-24$ weeks of gestational age) (original magnification $\times 400)$. 


\section{Adhesion molecules in human skin development}

and perturbed terminal differentiation. ${ }^{14,15}$ The understanding of integrin expression from early development control is therefore important to elucidate its level of expression and the correlation to keratinocytes both in normal condition of the skin and in epidermal disorders.

Composed, our results have shown that intermediate filaments and adhesion molecules during skin development are tightly regulated and their expression is orchestrated to enable the correct formation of the epidermis. It has also been clear that adhesion structures are fundamental for this process and they are present, although not mature, from the very initial phases of skin development. Additionally, adhesion molecules have shown variable patterns during the development of epidermis, suggesting their important roles in the formation of the various layers of the cutaneous epithelium. Yet, our results support the hypothesis that adhesion molecules, mainly integrins, are indispensable in the early phases of organogenesis and, in an adult phase, in the morphological integrity and tissue function maintenance. These evidence may have potential applications for diagnosis of genetic disorders of cell adhesion or epithelial maturation when amniocentesis is performed, especially in disorders involving hemidesmosomal attachment complexes and diseases related to mutations of epidermal keratins. ${ }^{16,17}$

At present, we are investigating the different patterns and roles of these adhesion molecules in the layers of epidermis to understand possible pattern changes of their expression in skin diseases.

\section{Acknowledgement}

Fundagão de Amparo à Pesquisa do Estado de São Paulo (FAPESP) grant 05/59556-1.

\section{References}

1. Hirai Y, Nose A, Kobayashi S, Takeichi M. Expression and role of $\mathrm{E}$ - and P-cadherin adhesion molecules in embryonic histogenesis. II. Skin morphogenesis. Development 1989; 105: 271.
2. Hentula M, Peltonen J, Peltonen S. Expression profiles of cellcell and cell-matrix junction proteins in developing human epidermis. Arch Dermatol Res 2001; 293: 259.

3. Dale BA, Holbrook KA, Kimball JR, Hoff M, Sun T. Expression of epidermal keratins and filaggrin during human fetal skin development. J Cell Biol 1985; 101: 1257.

4. Moll R, Moll I, Wiest W. Changes in the patterns of cytokeratins polypeptides in epidermis and hair follicles during skin development in human fetuses. Differentiation 1983; 23: 170.

5. Lee SC, Lee JB, Kook JP, et al. Expression of differentiation markers during fetal skin development in humans: immunohistochemical studies on the precursor proteins forming the cornified cell envelope. J Invest Dermatol 1999; 112: 882.

6. Furukawa F, Fujii K, Horiguchi Y, et al. Roles of E- and P-cadherin in the human skin. Microsc Res Tech 1997; 38: 343.

7. Banks-Schlegel SP. Keratin alterations during embryonic epidermal differentiation: a presage of adult epidermal maturation. J Cell Biol 1982; 93: 551.

8. Kasper M, Stosiek P. Immunohistochemical investigation of different cytokeratins and vimentin in the human epididymis from fetal period up to adulthood. Cell Tissue Res 1989; 257: 661.

9. Koizumi M, Matsuzaki T, Ihara S. Expression of P-cadherin distinct from that of E-cadherin in re-epithelization in neonatal rat skin. Dev Growth Differ 2005; 47: 75.

10. Hertle MD, Adams JC, Watt FM. Integrin expression during human epidermal development in vivo and in vitro. Development 1991; 112: 192.

11. Fine JD, Smith LT, Holbrook KA, Katz SI. The appearance of four basement membrane zone antigens in developing human fetal skin. J Invest Dermatol 1984; 83: 66.

12. Lane TA, Helm KF, Goldsmith LA. Identification of bullous pemphigoid, pemphigus, laminin and anchoring fibril antigens in human fetal skin. J Invest Dermatol 1985; 84: 27.

13. Mc Millan JR, Eady RAJ. Hemidesmosome ontogeny in digit skin of the human fetus. Arch Dermatol Res 1996; 288: 91.

14. Watt FM, Hertle MD. Keratinocyte integrins. In Leigh IM, Lane IB, Eatt FM, eds. The keratinocyte handbook. Cambridge Universitiy Press, Cambridge, UK, 1994; 153.

15. Hotchin N, Gandarilas A, Watt FM. Regulation of cell surface beta-1 integrin levels during keratinocyte terminal differentiation. J Cell Biol 1995; 128: 1209.

16. Uitto J, Richard G, McGrath JA. Diseases of epidermal keratins and their linker proteins. Exp Cell Res 2007; 313: 1995.

17. Nakano A, Pulkkinen L, Murrell D, et al. Epidermolysis bullosa with congenital pyloric atresia: novel mutations in the beta-4 integrin gene (ITGB4) and genotype/phenotype correlations. Pediatr Res 2001; 49: 618. 